\title{
Effects of growth stage and growing degree day accumulations on triticale forages: 1. Dry matter yield, nutritive value, and in vitro dry matter disappearance
}

\author{
W. K. Coblentz, ${ }^{* 1}$ M. S. Akins, † K. F. Kalscheur, $\ddagger$ G. E. Brink, $\ddagger$ and J. S. Cavadini§ \\ *USDA Agricultural Research Service, US Dairy Forage Research Center, Marshfield, WI 54449 \\ †Department of Dairy Science, University of Wisconsin, Madison 53706 \\ ¥USDA Agricultural Research Service, US Dairy Forage Research Center, Madison, WI 53706 \\ §University of Wisconsin Marshfield Agricultural Research Station, Marshfield 54449
}

\section{ABSTRACT}

The use of triticale (X Triticosecale Wittmack) in dairy-cropping systems has expanded greatly in recent years, partly to improve land stewardship by providing winter ground cover. Our objective was to establish relationships relating indices of nutritive value with growth stage or accumulated growing degree days $>5^{\circ} \mathrm{C}$ for triticale forages grown in central Wisconsin. Replicated $3.7-\mathrm{m} \times 9.1-\mathrm{m}$ plots were established following removal of corn for silage (fall 2015) and soybeans (fall 2016) and then harvested at various growth stages the following spring. Plants were assigned a numerical growth stage based on a linear staging system suitable for use as an independent regression variable. Response variables [e.g., dry matter (DM) yield, indices of nutritive value, and parameters from in vitro DM disappearance kinetics] were regressed on growth stage and growing degree days using linear, quadratic, cubic, or quartic models. For spring 2016, the mean DM yield at the boot stage $(3,804 \mathrm{~kg}$ of DM/ha) was only $30 \%$ of that observed at the soft dough stage of growth $(12,642 \mathrm{~kg}$ of $\mathrm{DM} / \mathrm{ha})$. Although yields were reduced during spring 2017, primarily due to spring flooding, the relationship between respective yields at these growth stages was similar (1,453 vs. $5,399 \mathrm{~kg}$ of $\mathrm{DM} / \mathrm{ha})$. Regressions of DM yield ( $\mathrm{kg} / \mathrm{ha})$ on growth stage for 2016 were explained by a cubic model $(\mathrm{Y}=$ $\left.0.0663 \mathrm{x}^{3}-9.44 \mathrm{x}^{2}+595 \mathrm{x}-9,810\right)$ compared with a simple linear response for $2017(\mathrm{Y}=103 \mathrm{x}-3,024)$; in both cases, coefficients of determination were very high $\left(\mathrm{R}^{2} \geq 0.934\right)$. Many nutritional and in vitro DM disappearance characteristics were affected by the juxtaposition and balance of 2 generally competing factors: (1) increased concentrations of structural plant fiber

Received April 3, 2018.

Accepted May 28, 2018.

${ }^{1}$ Corresponding author: wayne.coblentz@ars.usda.gov coupled with concurrent lignification as plants matured and (2) the accumulation of highly digestible carbohydrate during seed head development. A comparison of respective energy yields between the boot and soft dough stages of growth for 2016 (2,488 vs. $8,141 \mathrm{~kg}$ of total digestible nutrients/ha) and 2017 (1,033 vs. 3,520 $\mathrm{kg}$ of total digestible nutrients/ha) suggests that yields of energy are greater at soft dough stage and are mostly driven by DM yield. An informed harvest management decision for lactating cows may still favor a boot-stage harvest because of superior nutritional characteristics, a need to plant double-cropped corn expeditiously, or both. Harvest timing of triticale forages for other livestock classes would appear to be more flexible, but prioritizing a subsequent double crop may reduce the effects on DM yield to a secondary consideration.

Key words: double cropping, harvest timing, nutritive value, triticale

\section{INTRODUCTION}

The use of triticale (X Triticosecale Wittmack) in dairy-cropping systems has expanded greatly in recent years, partly in response to environmental pressures, such as a desire to capture $\mathrm{N}$ from land-applied manure or to improve stewardship of the land by providing winter ground cover. However, triticale also is recognized as a valuable forage crop (McCormick et al., 2006; Gibson et al., 2007; Baron et al., 2012) with the potential for use across a range of livestock classes, but appropriate use of triticale requires proper synchronization of forage nutrient composition with the nutrient demands of each livestock class. Generally, triticale functions as a winter-annual forage; most production scenarios in the north-central United States focus on fall establishment after removal of corn for silage or soybeans (Schwarte et al., 2005; Gibson et al., 2007), followed by harvest as silage the following spring or early summer. However, when this production strategy is used, accumulation of 
DM during spring is affected negatively by delayed fall planting dates, which has been attributed to inadequate leaf area, and reduced light interception that subsequently reduces the rate of spring growth (Schwarte et al., 2005).

Several previous studies have attempted to provide some guidance concerning proper agronomic or harvest management for triticale. These studies have used a wide scope of perspectives that include (1) assessment of fall growth alone (Coblentz and Walgenbach, 2010), (2) assessment of fall and spring growth combined (Maloney et al., 1999; McCormick et al., 2006), (3) multiple species comparisons established in monocultures or mixtures (Cherney and Marten, 1982a; Khorasani et al., 1997; McCormick et al., 2006), (4) focused emphasis on the effects of plant maturity on forage quality (Khorasani et al., 1997; Cherney and Marten, 1982a,b), (5) assessment of simulated grazing or haying scenarios on DM yield (Drake and Orloff, 2005), (6) N and P fertilization strategies and their subsequent effects on forage quality (Harmoney and Thompson, 2005), (7) timing of seeding dates and their effects on fall and spring DM yield and associated forage quality (Griggs, 2006), and (8) substitution of triticale for corn silage in diets of midlactation cows (Harper et al., 2017). Generally, recommendations for harvest of high-energy forage suitable for dairy cows are to cut when the flag leaf is fully emerged but no seed heads are visible (Kilcer et al., 2010). When this harvest schedule has been used, triticale silage has been successfully substituted for corn silage at a rate of $10 \%$ of dietary DM (Harper et al., 2017). Historically, harvests at the late milk to early dough stages of growth also have been common (McDonald et al., 1991; McCartney and Vaage, 1994; Kennelly and Weinberg, 2003). Using that management scheme, triticale silage was found to be less acceptable than barley or oat silage for beef heifers and sheep, based primarily on poor palatability and reduced DMI (McCartney and Vaage, 1994). Additional perspective is needed to relate indices of nutritive value to growth stage or growing degree days (GDD) for spring harvests of triticale forages established the previous fall after removal of corn for silage or soybeans. From a practical perspective, this production scenario has proved to be somewhat challenging throughout central Wisconsin. Growing seasons are relatively short, and soils are heavy and poorly drained; both of these conditions complicate the processes of removing a corn silage or soybean crop, applying dairy manure, and establishing a subsequent triticale double crop for harvest the following spring. Our objectives were to establish relationships relating indices of nutritive value with growth stage or accumulated GDD for triticale forages grown under a challenging double-cropping environment in central Wisconsin.

\section{MATERIALS AND METHODS}

\section{Forage Establishment and Management}

2015-2016. Thirty 3.7-m × 9.1-m plots were established in 5 field blocks (6 plots/block) on a Loyal silt loam soil at the University of Wisconsin Marshfield Agricultural Research Station, located near Stratford, Wisconsin $\left(44^{\circ} 39^{\prime} \mathrm{N}, 90^{\circ} 08^{\prime} \mathrm{W}\right)$. Blocks were established based on soil topography (slope). 'Forerunner' triticale (Legacy Seeds, Scandinavia, WI) was no-till drilled (model 1206NT; Great Plains Manufacturing, Salina, KS) into each plot of residual corn silage stubble (without tillage) at a seeding rate of $108 \mathrm{~kg} / \mathrm{ha}$ on September 30, 2015. Immediately before planting, the plot area received 56,100 L/ha of dairy slurry via a broadcasttype tank spreader. Soil samples were taken by block to a $0.15-\mathrm{m}$ depth the following spring (April 19); tests indicated $\mathrm{pH}=7.1 \pm 0.19, \mathrm{OM}=3.8 \pm 0.29 \%, \mathrm{P}=99$ $\pm 5.1 \mathrm{mg} / \mathrm{kg}$, and $\mathrm{K}=229 \pm 28.7 \mathrm{mg} / \mathrm{kg}$ (University of Wisconsin Soil and Forage Laboratory, Marshfield, WI). Plots were broadcast fertilized with urea (46-0-0) at a rate of $52 \mathrm{~kg}$ of N/ha on May 2 .

2016-2017. Thirty 3.7-m $\times$ 9.1-m plots were established in 5 field blocks on a Withee silt loam soil, again at the University of Wisconsin Marshfield Agricultural Research Station. The actual number of field blocks in the study was reduced to 4 because 1 block was lost due to flooding damage created by wet conditions during April 2017 (Table 1). 'Forerunner' triticale was not available before establishment in 2016; therefore, 'Tri-Cal' triticale (Byron Seeds LLC, Rockville, IN) was substituted and no-till drilled into soybean stubble as described previously at a seeding rate of $108 \mathrm{~kg} /$ ha on October 22, 2016. No dairy slurry was applied during the fall of 2016, in part because the previous crop was soybeans. Soil samples were taken by block to a $0.15-\mathrm{m}$ depth the following spring (May 7); tests indicated $\mathrm{pH}=7.1 \pm 0.05, \mathrm{OM}=3.4 \pm 0.13 \%, \mathrm{P}=$ $26 \pm 3.9 \mathrm{mg} / \mathrm{kg}$, and $\mathrm{K}=129 \pm 4.6 \mathrm{mg} / \mathrm{kg}$. Plots were then broadcast fertilized with urea (46-0-0) at a rate of $52 \mathrm{~kg}$ of N/ha on May 8.

Weather. All weather data (Table 1) reported for this project were obtained from the University of Wisconsin Marshfield Agricultural Research Station, and $30-y r$ monthly means for temperature and precipitation were obtained from NOAA (2002). Growing degree days were calculated using the averaging method with a $5^{\circ} \mathrm{C}$ base temperature: GDD $=[($ maximum daily temperature - minimum daily temperature) $/ 2]-5^{\circ} \mathrm{C}$, 
where GDD were then summed over the desired growing interval. For this analysis, GDD accumulations began on January 1, thereby omitting any GDD from the previous fall. A value of 0 was assumed for any individual day when the calculated GDD was $<0$.

\section{Harvest Management}

2015-2016. Within each block, the 6 plots were assigned randomly to 1 of 6 harvest dates. For 2016, these dates corresponded to a clear progression of advancing growth stages: (1) vegetative (May 12), (2) stem elongation (May 19), (3) boot (May 25), (4) heading (May 31), (5) anthesis (June 9), and (6) soft dough (July 1). On designated sampling dates, two 9.1-m-long swaths were removed from each plot with a 1.07-m-wide flail-type forage plot harvester equipped with load cells, thereby allowing electronic collection of wet plot weights. Plots were harvested to a $7.5-\mathrm{cm}$ stubble height. Within each plot, a grab subsample $(\sim 1,200 \mathrm{~g})$ was removed from the collection box for each swath, placed in a $42-\mathrm{cm} \times$ 30-cm cloth bag (Legend Inc., Sparks, NV), and dried under forced air at $55^{\circ} \mathrm{C}$ to constant weight $(\sim 96 \mathrm{~h})$. Dry weights from each sample bag were then used to calculate 2 estimates of forage DM concentration for each plot; these were then averaged before subsequent calculations of DM yield. Dried samples from each plot were composited and then retained for subsequent analysis of nutritive value. On each harvest date, canopy height was determined from 3 random locations/plot. Canopy height was measured to the tip of inflorescence or the apex of the highest leaf, whichever was taller. In addition, 3 plants/plot were assessed for growth stage using the linear model of Stauss (1994), where tillering $=20$ to 29 , stem elongation $=30$ to 39 , booting $=40$ to 49 , heading $=50$ to 59 , anthesis $=60$ to 69 , seed development $=70$ to 79 , and seed ripening $=80$ to 89 .
2016-201\%. Harvests during the second year of the trial were conducted with procedures identical to those described for 2015 to 2016. Although it was our intention to match growth stages at harvest across years, this was not possible due to the wet conditions observed from April through June of 2017, when cumulative rainfall totaled $470 \mathrm{~mm}$ and was $56 \%$ greater than normal (Table 1). As such, some harvests had to be delayed because of muddy field conditions. Actual growth stages and harvest dates for 2017 were (1) elongation (May 24), (2) boot (May 29), (3) late boot (June 2 ), (4) early anthesis (June 8), (5) watery seed (June 23), and (6) soft dough (June 30).

\section{Laboratory Analysis}

Dried whole-plant triticale forages were ground through a 1-mm screen in a model 4 Wiley mill (Thomas Scientific, Swedesboro, NJ) and then sealed in plastic sample bags pending subsequent analysis for nutritive value. Concentrations of laboratory DM were determined by drying 1.0-g samples of each forage overnight in a convection oven at $105^{\circ} \mathrm{C}$; subsequently, whole-plant ash was determined from these same subsamples by combustion in a muffle furnace at $500^{\circ} \mathrm{C}$ for $6 \mathrm{~h}$. Forages were analyzed sequentially for NDF, ADF, hemicellulose, cellulose, and ADL using the batch procedures described by Ankom Technology Corp. (Macedon, NY) for an Ankom200 Fiber Analyzer. Heat-stable $\alpha$-amylase was included in the NDF analysis procedures, but sodium sulfite was omitted because it attacks lignin and therefore should be omitted from sequential analyses including ADL (Van Soest et al., 1991). Water-soluble carbohydrates (WSC) were quantified using the phenol-sulfuric acid reaction as described by Dubois et al. (1956), with final concentrations determined colorimetrically. Concentrations of

Table 1. Summary of weather data for Marshfield, Wisconsin, from August 2015 through July 2017

\begin{tabular}{|c|c|c|c|c|c|c|c|c|}
\hline \multirow[b]{2}{*}{ Month } & \multicolumn{4}{|c|}{ Mean monthly temperature, ${ }^{\circ} \mathrm{C}^{1}$} & \multicolumn{4}{|c|}{ Precipitation, $\mathrm{mm}^{1}$} \\
\hline & 2015 & 2016 & 2017 & 30-yr normal & 2015 & 2016 & 2017 & 30-yr normal \\
\hline January & - & -10.0 & -8.0 & -11.3 & - & 17 & 59 & 25 \\
\hline February & - & -6.1 & -3.3 & -8.0 & - & 18 & 37 & 22 \\
\hline March & - & 2.3 & -2.0 & -1.5 & - & 121 & 68 & 50 \\
\hline April & - & 5.7 & 8.1 & 6.6 & - & 46 & 151 & 75 \\
\hline May & - & 13.6 & 11.9 & 13.2 & - & 72 & 145 & 94 \\
\hline June & - & 18.9 & 18.3 & 18.5 & - & 168 & 174 & 105 \\
\hline July & - & 21.0 & 20.9 & 21.0 & - & 110 & 105 & 103 \\
\hline August & 19.2 & 20.8 & - & 19.6 & 78 & 99 & - & 110 \\
\hline September & 18.3 & 16.6 & - & 14.3 & 169 & 151 & - & 102 \\
\hline October & 8.9 & 10.2 & - & 8.1 & 58 & 55 & - & 63 \\
\hline November & 4.1 & 5.4 & - & -0.4 & 68 & 48 & - & 58 \\
\hline December & -0.6 & -7.4 & - & -8.2 & 126 & 53 & - & 33 \\
\hline
\end{tabular}

${ }^{1}$ NOAA (2002). 
$\mathrm{N}$ in each sample were assessed by a rapid combustion procedure (model TruMac CN, Leco Corp., St. Joseph, MI), and a conversion factor of 6.25 was used to calculate $\mathrm{CP}$. The total forage $\mathrm{CP}$ pool was further partitioned by nonsequential digestions in neutral or acid detergent (NDICP and ADICP, respectively), where $\mathrm{CP}$ within each residue was quantified with the rapid combustion procedure described previously. For determinations of NDICP, the NDF solution contained heat-stable $\alpha$-amylase but no sodium sulfite, which is known to cleave disulfide bonds and dissolve crosslinked proteins, thereby reducing recovery of $\mathrm{CP}$ from NDF residues (Van Soest et al., 1991). The summative approach was used to calculate energy density (TDN), where the ADL option was used to estimate truly digestible fiber (Weiss et al., 1992; NRC, 2001) and $\mathrm{NE}_{\mathrm{L}}$ was calculated as described by NRC (2001).

\section{Apparent In Vitro Disappearance of DM and Rate Kinetics}

An in-depth assessment of apparent in vitro DM disappearance (IVDMD) was conducted on forages harvested during 2016 using the Ankom Daisy II Incubator System (Ankom Technology Corp.). To limit sample numbers to a manageable scope, triticale forages harvested at the vegetative stage of growth were eliminated from the sample set. This stage of growth was selected for elimination because it is unlikely that any livestock producer would harvest triticale for silage at that immature growth stage, and in-depth analysis of nutritive value indicated only minor differences between the vegetative and stem elongation stages of growth. Subsamples $(0.30 \mathrm{~g})$ of each forage harvested in $2016(\mathrm{n}=25)$ were heat sealed in F57 fiber filter bags and incubated in quadruplicate for $3,6,9,12$, $18,24,36,48,72,96,144$, or $240 \mathrm{~h}$ as recommended by Ankom Technology Corp. Prior to loading the F57 filter bags with sample, each empty fiber bag was prerinsed in acetone and air dried per instructions of the aforementioned manufacturer. The $0.30 \mathrm{-g}$ sample size was retained across all incubation times and was selected as a compromise between the smaller sample size $(0.25 \mathrm{~g})$ recommended by the manufacturer for short incubation times and ensuring that adequate residue remained after the 240-h incubations, some of which included highly digestible forages. Quadruplicate incubations were conducted in 3 identical incubator boxes such that (1) each forage-incubation time combination was represented (in singlet) within each of 4 runs, (2) each fermentation jar containing a specific incubation time was placed in a different box position (top right, top left, bottom right, and bottom left) during each of the 4 runs, and (3) each jar containing a specific incubation time was evaluated at least once in each of the 3 incubator boxes. These procedures were used as an extra precaution against bias created by run-to-run variability. In addition, the temperature within each incubator box was standardized $\left(39^{\circ} \mathrm{C}\right)$ to an independent thermometer before conducting the incubations. Rumen fluid used in the inoculum was obtained from 2 nonlactating Holstein cows offered a forage-based diet comprising (DM basis) alfalfa haylage (53.4\%), corn silage $(21.4 \%)$, and chopped wheat straw $(25.2 \%)$. Nutrient composition of the diet was $12.6 \% \mathrm{CP}, 49.2 \% \mathrm{NDF}$, $11.1 \%$ starch, $2.46 \%$ ether extract, and $59.0 \%$ TDN; University of Wisconsin Soil and Forage Laboratory). Rumen fluid was siphoned from each cow with a handoperated pump through a ruminal cannula directly into prewarmed $\left(39^{\circ} \mathrm{C}\right)$ insulated bottles and then transported to the laboratory. Insulated bottles were placed in a chest-type insulated cooler during transport. After filtering the rumen fluid through 4 layers of cheesecloth, a total of $400 \mathrm{~mL}$ of rumen fluid with equal contributions from each donor cow was added to each incubation jar containing buffers and samples. The head space within each incubation jar was purged twice with $\mathrm{CO}_{2}$; these purges were conducted immediately after buffers and sample bags were added to the incubation jars for prewarming to $39^{\circ} \mathrm{C}$ and immediately after rumen fluid was added to each incubation jar before final lid placement and subsequent incubation.

The 4 values obtained for each combination of forage and incubation time were averaged before any assessment of rate kinetics. Disappearance kinetics of DM were calculated based on 3 pools of DM, where fraction A represented the percentage of forage DM disappearing at a rate too fast to measure, fraction $\mathrm{B}$ was the percentage of DM disappearing at a measurable rate, and fraction $U$ was considered to be the percentage of DM indigestible in buffered rumen fluid. Data were fitted by nonlinear regression (PROC NLIN; SAS Institute, 2010) using options BEST $=10$ and METHOD = Marquardt for the following model:

$$
\text { DM remaining }(\%)=\left\{\mathrm{B} \times \mathrm{e}^{\left[-\mathrm{K}_{\mathrm{d}} \times(\mathrm{T}-\mathrm{L})\right]}\right\}+\mathrm{U},
$$

where $\mathrm{K}_{\mathrm{d}}=\mathrm{DM}$ disappearance rate per hour, $\mathrm{T}=$ incubation time $(\mathrm{h})$, and $\mathrm{L}=$ discrete lag time $(\mathrm{h})$. Therefore, L can be described as the time interval required before disappearance of fraction B begins. An additional condition was placed on the regression model whenever $\mathrm{L}>\mathrm{T}$; under those conditions, $\mathrm{DM}$ remaining $(\%)=\mathrm{B}+\mathrm{U}$. Fraction $\mathrm{A}$ was calculated as $A=100 \%-(B+U)$. Within this analysis, $U$ was 
determined by nonlinear regression and, although very similar, it was not equated arbitrarily to the DM remaining after the 240 -h incubation.

\section{Statistics}

For all response variables, PROC MEANS of SAS (SAS Institute, 2010) was used to calculate the mean and standard deviation for either 5 (2016) or 4 (2017) field replications on each harvest date. Response variables obtained for each individual plot (experimental unit) were then regressed against growth stage or GDD accumulated from January 1 using PROC REG of SAS (SAS Institute, 2010). For each response variable evaluated, linear, quadratic, cubic, and quartic models were considered. Selection of the most appropriate model required a significant $(P<0.05)$ coefficient for each polynomial term coupled with the greatest possible coefficient of determination $\left(\mathbf{R}^{2}\right)$; however, to avoid overfitting, higher-ordered models were eliminated from consideration when there were not clear physiological explanations for the complex character of the curve. The intercept was retained in the model irrespective of whether it differed $(P<0.05)$ from 0.

\section{RESULTS AND DISCUSSION}

\section{Weather}

Mean monthly temperature and precipitation data (Table 1) describe 2 production years that differed from each other primarily on the basis of spring precipitation. For 2017, rainfall exceeded the expected norms by $101 \%$ in April, $54 \%$ in May, and $66 \%$ in June, totaling $470 \mathrm{~mm}$ over that 3 -mo period. As mentioned previously, this resulted in periods of standing water and some subsequent stand loss during 2017. For both production seasons, rainfall during September exceeded normal expectations (102 mm; NOAA, 2002), totaling 169 and $151 \mathrm{~mm}$ for 2015 and 2016, respectively. In addition, mean monthly temperatures for November 2015 $\left(4.1^{\circ} \mathrm{C}\right)$ and November $2016\left(5.4^{\circ} \mathrm{C}\right)$ were both warmer than the 30 -yr normal $\left(-0.4^{\circ} \mathrm{C}\right)$.

\section{Agronomic Characteristics}

Agronomic characteristics of triticale forages are summarized in Table 2. Sharp contrasts existed between the 2 often-observed growth stages (boot or soft dough) for harvest (Kennelly and Weinberg, 2003; Kilcer et al., 2010). Based on these results, producers could expect to harvest triticale for silage at boot stage during the last week of May and at soft dough around July 1 throughout central Wisconsin. At boot stage (stage $=43$ ), canopy heights were $68 \mathrm{~cm}$ in 2016 and $60 \mathrm{~cm}$ in 2017; however, canopy heights had more than doubled $(\geq 142 \mathrm{~cm})$ by the soft dough stage of growth during both production years. Although plants harvested at the boot stage exhibited percentages of DM $(\leq 17.3 \%)$ that clearly would require field wilting before ensiling, the DM concentrations at the soft dough stage of growth $(\geq 35.4 \%)$ exceed a common threshold

Table 2. Agronomic characteristics of triticale forages harvested at Marshfield, Wisconsin, during 2016 and 2017

\begin{tabular}{|c|c|c|c|c|c|c|c|c|c|c|}
\hline \multirow{2}{*}{$\begin{array}{l}\text { Harvest } \\
\text { date }\end{array}$} & \multirow{2}{*}{$\begin{array}{l}\text { Descriptive } \\
\text { growth stage }\end{array}$} & \multirow[b]{2}{*}{$\mathrm{GDD}^{1}$} & \multicolumn{2}{|c|}{ Stage (linear) ${ }^{2}$} & \multicolumn{2}{|c|}{$\begin{array}{c}\text { Canopy } \\
\text { height, }{ }^{3} \mathrm{~cm}\end{array}$} & \multicolumn{2}{|c|}{$\begin{array}{l}\text { Harvest } \\
\text { DM, \% }\end{array}$} & \multicolumn{2}{|c|}{$\begin{array}{c}\text { DM yield, } \\
\mathrm{kg} \text { of } \mathrm{DM} / \mathrm{ha}\end{array}$} \\
\hline & & & $\operatorname{Mean}^{4}$ & $\mathrm{SD}^{4}$ & Mean & $\mathrm{SD}$ & Mean & $\mathrm{SD}$ & Mean & $\mathrm{SD}$ \\
\hline \multicolumn{11}{|l|}{2016} \\
\hline May 12 & Vegetative & 195 & 30 & 0.4 & 37 & 3.7 & 14.2 & 1.44 & 1,203 & 182.5 \\
\hline May 19 & Elongation & 220 & 32 & 0.4 & 47 & 3.8 & 16.9 & 0.51 & 1,825 & 331.3 \\
\hline May 25 & Boot & 300 & 43 & 1.2 & 68 & 4.9 & 15.5 & 0.99 & 3,804 & 653.2 \\
\hline July 1 & Soft dough & 817 & 84 & 0.5 & 144 & 2.3 & 35.4 & 1.22 & 12,642 & 762.4 \\
\hline \multicolumn{11}{|l|}{2017} \\
\hline May 24 & Elongation & 269 & 35 & 4.5 & 43 & 7.8 & 18.0 & 0.93 & 715 & 335.0 \\
\hline May 29 & Boot & 321 & 43 & 0.3 & 60 & 2.4 & 17.3 & 0.19 & 1,453 & 333.3 \\
\hline June 2 & Late boot & 355 & 49 & 4.1 & 66 & 9.9 & 20.0 & 0.38 & 1,800 & 294.8 \\
\hline June 8 & Early anthesis & 447 & 60 & 1.4 & 112 & 15.0 & 20.6 & 0.91 & 3,018 & 878.7 \\
\hline June 23 & Watery seed & 676 & 71 & 0.4 & 135 & 4.5 & 32.8 & 0.42 & 4,483 & 560.8 \\
\hline
\end{tabular}

${ }^{1}$ Growing degree days accumulated from January 1 using $5{ }^{\circ} \mathrm{C}$ as a base temperature.

${ }^{2}$ Stage of growth identified as tillering (20-29), stem elongation (30-39), booting (40-49), heading (50-59), anthesis (60-69), seed development (70-79), and seed ripening (80-89; Stauss, 1994).

${ }^{3}$ Canopy height measured to the apex of the highest leaf or the tip of inflorescence, whichever was taller.

${ }^{4}$ Mean and SD based on 5 field replications on each harvest date for 2016 and 4 field replications for 2017. 
(30\%; Muck and Kung, 2007) for avoiding problematic clostridial fermentations and production of effluent in many silo types. As such, direct cutting at soft dough appears to be a viable option.

Perhaps most important, there were stark differences in DM yield between these 2 growth stages. During 2016, plots produced $12,642 \mathrm{~kg}$ of $\mathrm{DM} /$ ha at the soft dough stage of growth, but only $30.1 \%$ of that amount was harvested at boot stage $(3,804 \mathrm{~kg}$ of DM/ha). Although overall forage production was greatly affected by flooding and standing water during 2017, thereby reducing DM yields at all growth stages compared with 2016 , the relative percentage associated with a bootstage harvest compared with soft dough was similar $(26.9 \%)$. This yield drag associated with a boot-stage harvest of triticale was severe but has been documented in reports for other cereal grain forages. Edmisten et al. (1998) harvested barley, oat, rye, and wheat forages at multiple growth stages over 3 yr in North Carolina; yield comparisons between boot- and soft dough-stage harvests always resulted in a yield drag with an earlier harvest, but yields at boot stage ranged between 47.4 and $63.9 \%$ of those at soft dough in 8 of 10 species-production year combinations. A yield comparison (42.2\%) between these growth stages for barley in Virginia was comparable in scope (Acosta et al., 1991); generally, yield differentials between the boot and soft dough stages of growth have been more favorable for other cereal grain forages than observed in the present study for triticale. Strictly from an agronomic standpoint, an approximate $70 \%$ reduction in yield realized by adopting a boot-stage harvest management strategy may seem excessive; however, in central Wisconsin, delaying harvests until July 1 to obtain peak DM yield would preclude the possibility of double-cropping corn or soybeans after removing the triticale forage.

The most appropriate regression model relating DM yield with growth stage or GDD varied across years (Figure 1), but coefficients of determination remained very high in all cases $\left(\mathrm{R}^{2} \geq 0.915\right)$. Higher-ordered models were required to describe DM yield for 2016, which contrasted with the simple linear relationships that were identified for 2017. These differences in the complexity of regression models between years may have been related to the lack of alignment with respect to growth stages at harvest as well as the flooding and unfavorable weather observed during 2017 that negatively affected DM yields. Previously, curvilinear relationships between DM yield and GDD for triticale forages have been reported (Schwarte et al., 2005; Gibson et al., 2007), and exceptionally high coefficients of determination $\left(\mathrm{R}^{2} \geq 0.85\right)$ have been noted in studies across several locations with a common $\mathrm{N}$ fertilization rate (Schwarte et al., 2005).

\section{Nutritive Value}

$\boldsymbol{N D F}$ and $\boldsymbol{A D F}$. Despite the precipitation differences across production years, concentrations of NDF and ADF (Figure 2) changed in similar patterns as a function of growth stage. Generally, NDF and ADF increased beginning at stem elongation and continued through anthesis in 2016, but the maximum shifted slightly to an early seed development stage in 2017. For 2016, mean concentrations of NDF ranged from 41.3 to $66.3 \%$ across specific harvest dates (Table 3), with a similar range observed in 2017 (41.1-65.2\%). For ADF, concentrations across harvest dates ranged from 21.2 to $40.0 \%$ in 2016 and 21.8 to $40.5 \%$ in 2017 . After reaching an apex at the anthesis or the watery seed stages of growth, concentrations of both fiber components declined thereafter, as NDF and ADF were diluted by the partitioning of NSC into developing seed heads. Various forms of dilution response resulting in static or reduced concentrations of NDF at mature growth stages have been observed consistently for a variety of cereal grain forages (Cherney and Marten, 1982b; West et al., 1991; Coblentz et al., 2000). This dilution response for triticale was substantial in magnitude, reducing mean NDF by 9.8 percentage units between the anthesis and soft dough stages of growth in 2016 and by 5.7 percentage units between watery seed and soft dough in 2017 (Table 3). Regression models relating NDF or ADF with growth stage (Figure 2) were inconsistent across years, although the general response was similar and coefficients of determination were quite high $\left(\mathrm{R}^{2} \geq\right.$ 0.950). West et al. (1991) has described regression relationships between NDF and growth stage or GDD for wheat forages grown in Arkansas; in that study, clear effects of dilution via grain fill were illustrated, but regression models also differed between cultivars based largely on maturation rate. As mentioned previously, higher-ordered (quartic) models for our triticale forages may have been selected for 2016 because growth stages at harvest were not exactly aligned with 2017 and concentrations of NDF or ADF at the vegetative and stem elongation stages of growth were similar, whereas no vegetative harvest was obtained in 2017. Generally, dilution associated directly with grain fill contributed to the higher-ordered nature of all NDF and ADF regression models by reducing concentrations of these fiber components at advanced growth stages. Regressions of NDF and ADF on GDD (Table 4) were explained by quadratic $(P<0.001)$ models in all cases; however, coefficients of determination $\left(\mathrm{R}^{2} \geq 0.926\right)$ suggest that GDD also was an excellent predictor variable for these fiber components.

$\boldsymbol{A D \boldsymbol { L }}$. For both 2016 and 2017, concentrations of ADL (Table 3) exhibited a typical response to plant 

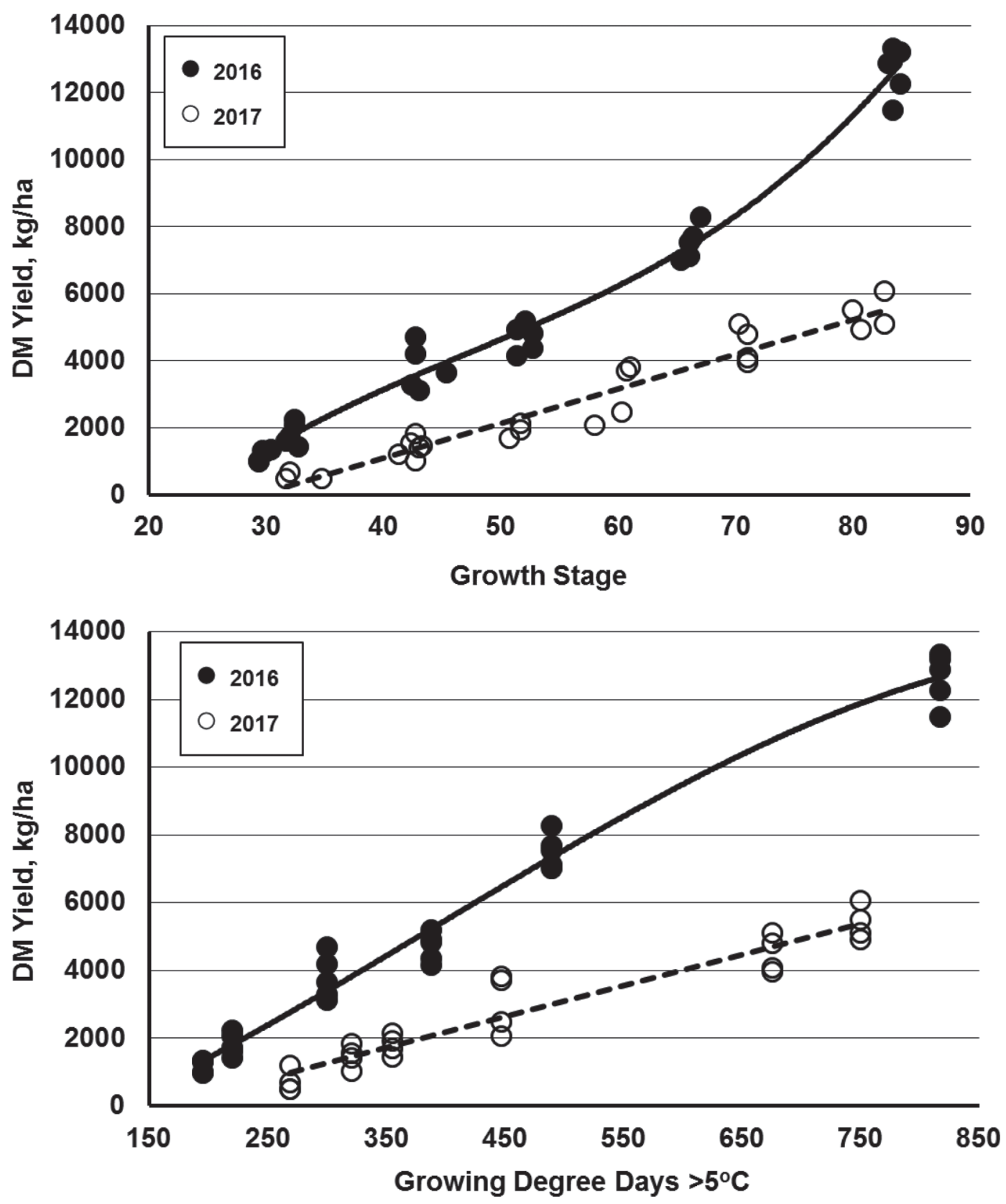

Figure 1. Regression relationships for DM yield on growth stage (top) and growing degree days (bottom; $5^{\circ} \mathrm{C}$ base temperature) for triticale forages harvested during 2016 and 2017 at Marshfield, Wisconsin. Regression equations on growth stage at harvest were as follows: 2016, Y = $0.0663 \mathrm{x}^{3}-9.44 \mathrm{x}^{2}+595 \mathrm{x}-9,810, \mathrm{R}^{2}=0.985$, root mean squared error $(\mathrm{RMSE})=508.1 \mathrm{~kg}$ of DM/ha; $2017, \mathrm{Y}=103 \mathrm{x}-3,024, \mathrm{R}^{2}=0.934$, $\mathrm{RMSE}=466.6 \mathrm{~kg}$ of $\mathrm{DM} / \mathrm{ha}$. Regression equations with growing degree days as the independent variable were as follows: $2016, \mathrm{Y}=-0.00590 \mathrm{x}^{2}$ $+24.3 \mathrm{x}-3,267, \mathrm{R}^{2}=0.980, \mathrm{RMSE}=578.1 \mathrm{~kg}$ of $\mathrm{DM} / \mathrm{ha} ; 2017, \mathrm{Y}=9.15 \mathrm{x}-1,486, \mathrm{R}^{2}=0.915, \mathrm{RMSE}=527.6 \mathrm{~kg}$ of $\mathrm{DM} / \mathrm{ha}$. The overall model for each regression was significant at $P<0.001$.

maturity, increasing with growth stage or GDD and reaching concentrations $\geq 4.07 \%$ at the soft dough stage of growth. Ambient temperature is positively associated with lignification (Ford et al., 1979; Van Soest, 1982) and likely contributed to these responses; however, our concentrations of ADL are somewhat less than those reported elsewhere for headed triticale silages (NRC,
$2001 ; 5.8 \%$ ). In contrast, cereal grain forages (oat) that joint and elongate during cooler fall temperatures typically exhibit very low concentrations of ADL (often $<2 \%$ ) and as a result are prone to extensive lodging in response to late-fall snowstorms (Coblentz and Walgenbach, 2010; Coblentz et al., 2013a,b). Unlike NDF and $\mathrm{ADF}$, dilution resulting from grain fill had only 

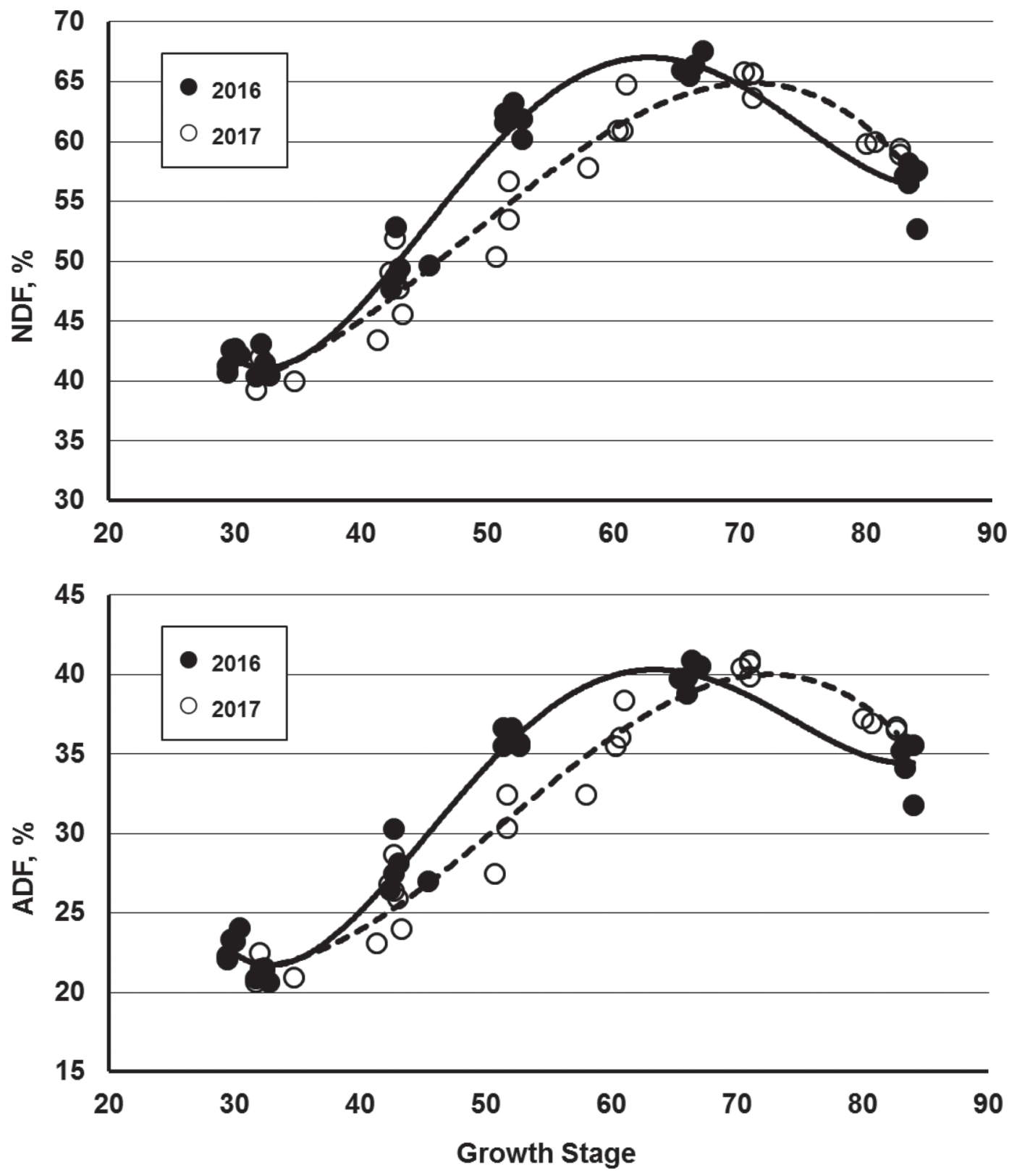

Figure 2. Regressions of NDF (top) on growth stage were as follows: $2016, \mathrm{Y}=0.0000369 \mathrm{x}^{4}-0.00886 \mathrm{x}^{3}+0.745 \mathrm{x}^{2}-25.4 \mathrm{x}+342.5, \mathrm{R}^{2}=$ 0.975 , root mean squared error (RMSE) $=1.67 \% ; 2017, \mathrm{Y}=-0.000570 \mathrm{x}^{3}+0.0828 \mathrm{x}^{2}-3.14 \mathrm{x}+74.9, \mathrm{R}^{2}=0.950$, RMSE $=2.06 \%$. For ADF (bottom), regression equations were as follows: 2016, $\mathrm{Y}=0.0000276 \mathrm{x}^{4}-0.00661 \mathrm{x}^{3}+0.557 \mathrm{x}^{2}-19.1 \mathrm{x}+250.7, \mathrm{R}^{2}=0.971, \mathrm{RMSE}=1.30 \%$; $2017, \mathrm{Y}=-0.000492 \mathrm{x}^{3}+0.0760 \mathrm{x}^{2}-3.26 \mathrm{x}+64.1, \mathrm{R}^{2}=0.956, \mathrm{RMSE}=1.53 \%$. The overall model for each regression was significant at $P<$ 0.001 .

mild effects on ADL, and mean concentrations of ADL (Table 3) increased across all harvest dates during 2016, ranging from 1.14 to $4.54 \%$. This response was explained by close quadratic $(P<0.001)$ relationships with both growth stage (Figure $3 ; \mathrm{R}^{2}=0.917$ ) and GDD (Table $\left.4 ; \mathrm{R}^{2}=0.920\right)$. Respective cubic $(P<$ $0.001)$ and quadratic $(P<0.001)$ models with high coefficients of determination $\left(\mathrm{R}^{2} \geq 0.967\right)$ were selected for 2017. Although responses for both years described curvilinear character, characterized by plateauing or mildly declining concentrations at advanced growth stages, the sharp depressions caused by grain fill that were described for NDF and ADF were not observed for ADL. Cherney and Marten (1982b) reported a sharp decline in ADL concentrations within the inflorescence of oat, triticale, wheat, and barley, but this did not offset collective increases in concentrations of ADL within the stem, leaf sheath, and leaf blade compo- 
nents on a whole-plant basis. Similar observations have been reported for a wide range of cereal grain forages in Michigan (Helsel and Thomas, 1987) and California (Meyer et al., 1957).

$\boldsymbol{A s h}$. Concentrations of ash generally declined with plant development, yielding higher-ordered models in 2017 compared with 2016, but each exhibited a close relationship $\left(R^{2} \geq 0.907\right)$ with growth stage (Figure 4$)$ or GDD (Table 4). The negative relationship between whole-plant ash concentrations and plant development has been observed with fall-grown oat, wheat, and triticale (Coblentz and Walgenbach, 2010), with concentrations ranging between 12.3 and $15.8 \%$ in mid-September when plants were in the vegetative or early stem elongation stages of growth. Similarly, spring growth of oat, triticale, wheat, and barley exhibited sharply declining concentrations of $\mathrm{K}$, Ca, P, and $\mathrm{Mg}$ as plants matured from the flag leaf stage to 28 d postappearance of the first awns or floret (Cherney and Marten, 1982a). In the present study, ash exceeded $10.2 \%$ through the May 25 harvest date during 2016 but was less on similar dates in $2017(\leq 7.2 \%)$. Ash does not contribute to overall energy estimates (NRC, 2001), and high concentrations of ash have depressed estimations of energy within immature fall oat forages (Coblentz et al., 2013b).

$\boldsymbol{W S C}$. The relationships between concentrations of WSC and growth stage or GDD were complex and were explained by a quartic $(P<0.001)$ model in all cases (Figure 5; Table 4). Generally, the relationship between WSC and growth stage exhibited 3 inflection points, which can be described as (1) an increase in WSC reaching an apex at the late stem elongation/early boot stage, (2) a subsequent decline reaching a minimum at early anthesis, and (3) an increase following anthesis that reached a plateau at the soft dough stage of growth. During both 2016 and 2017, there was an approximate 9-percentage-unit differential in WSC concentrations between late stem elongation and anthesis (Table 3), which likely occurred as cells expanded rapidly and forage plants partitioned carbohydrate into rapid plant growth. Increases in WSC after anthesis are likely associated with the cessation of rapid plant growth and initiation of grain fill. However, WSC also may decline as carbohydrate (particularly starch) is partitioned into the filling grain head at advanced growth stages. This has been illustrated for wheat, oat, and barley forages harvested at milk and dough stages of growth; respective concentrations of WSC declined by 39.2, 43.2, and $53.6 \%$ during this time interval (Bergen et al., 1991). Regardless, the soft dough stage of growth has often been considered desirable for harvest of cereal grain forages as silage (Helsel and Thomas, 1987; Acosta et al., 1991; McDonald et al., 1991). Despite the higher- 


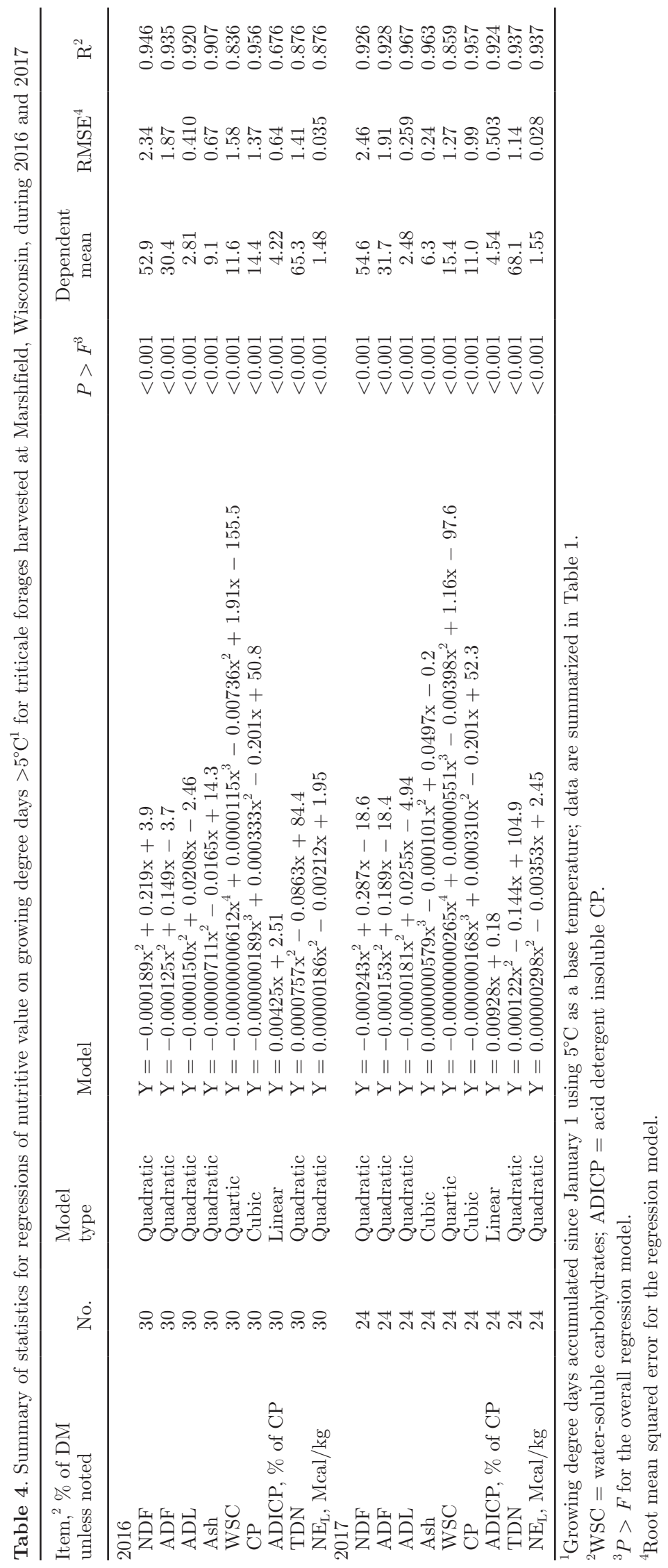




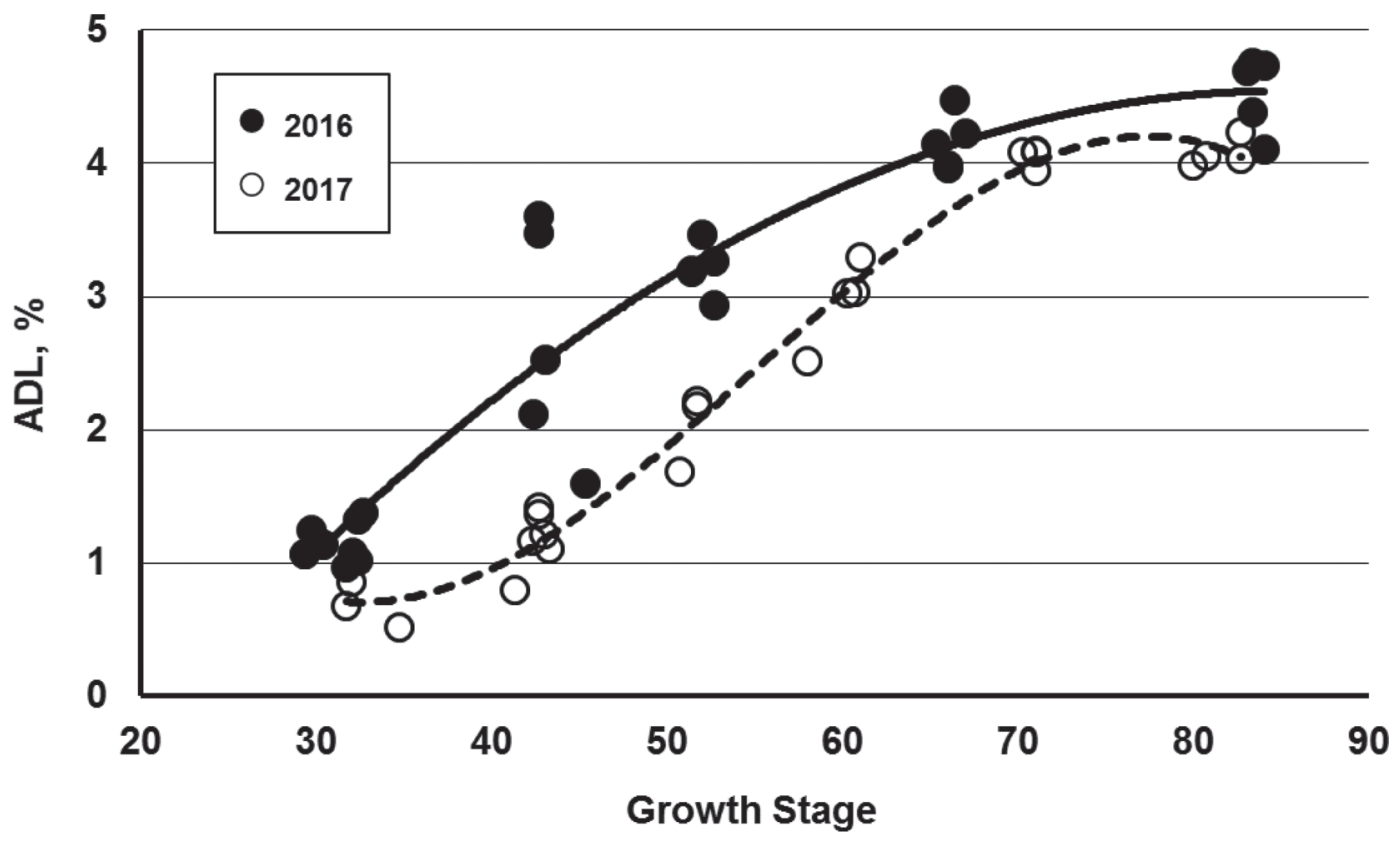

Figure 3. Regression relationships for ADL on growth stage for triticale forages harvested during 2016 and 2017 at Marshfield, Wisconsin. Regression equations were as follows: $2016, \mathrm{Y}=-0.00114 \mathrm{x}^{2}+0.195 \mathrm{x}-3.73, \mathrm{R}^{2}=0.917$, root mean squared error $(\mathrm{RMSE})=0.416 \% ; 2017, \mathrm{Y}$ $=-0.0000778 \mathrm{x}^{3}+0.0129 \mathrm{x}^{2}-0.590 \mathrm{x}+8.99, \mathrm{R}^{2}=0.986, \mathrm{RMSE}=0.170 \%$. The overall model for each regression was significant at $P<0.001$.

ordered (quartic) character of regressions of WSC on nutritive value. Respective $\mathrm{R}^{2}$ statistics for 2016 and growth stage or GDD, more variability was found in 2017 were 0.776 and 0.839 when growth stage was the these relationships than for most other measures of independent variable and 0.836 and 0.859 for GDD.

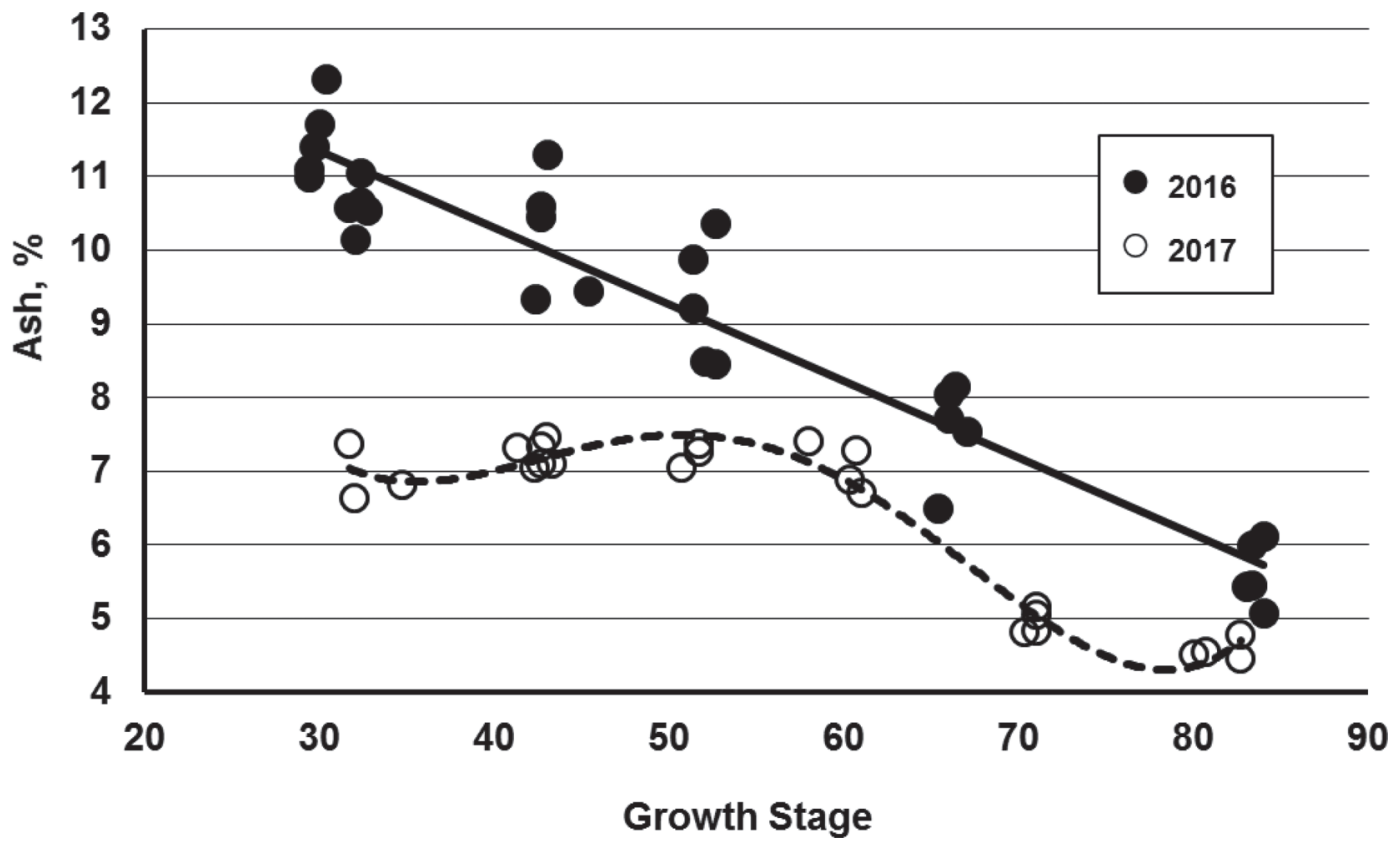

Figure 4. Regression relationships for whole-plant ash on growth stage for triticale forages harvested during 2016 and 2017 at Marshfield, Wisconsin. Regression equations were as follows: $2016, \mathrm{Y}=-0.104 \mathrm{x}+14.4, \mathrm{R}^{2}=0.907$, root mean squared error $(\mathrm{RMSE})=0.65 \%$; $2017, \mathrm{Y}$ $=0.00000776 \mathrm{x}^{4}-0.00170 \mathrm{x}^{3}+0.133 \mathrm{x}^{2}-4.39 \mathrm{x}+59.0, \mathrm{R}^{2}=0.958, \mathrm{RMSE}=0.26 \%$. The overall model for each regression was significant at $P$ $<0.001$. 


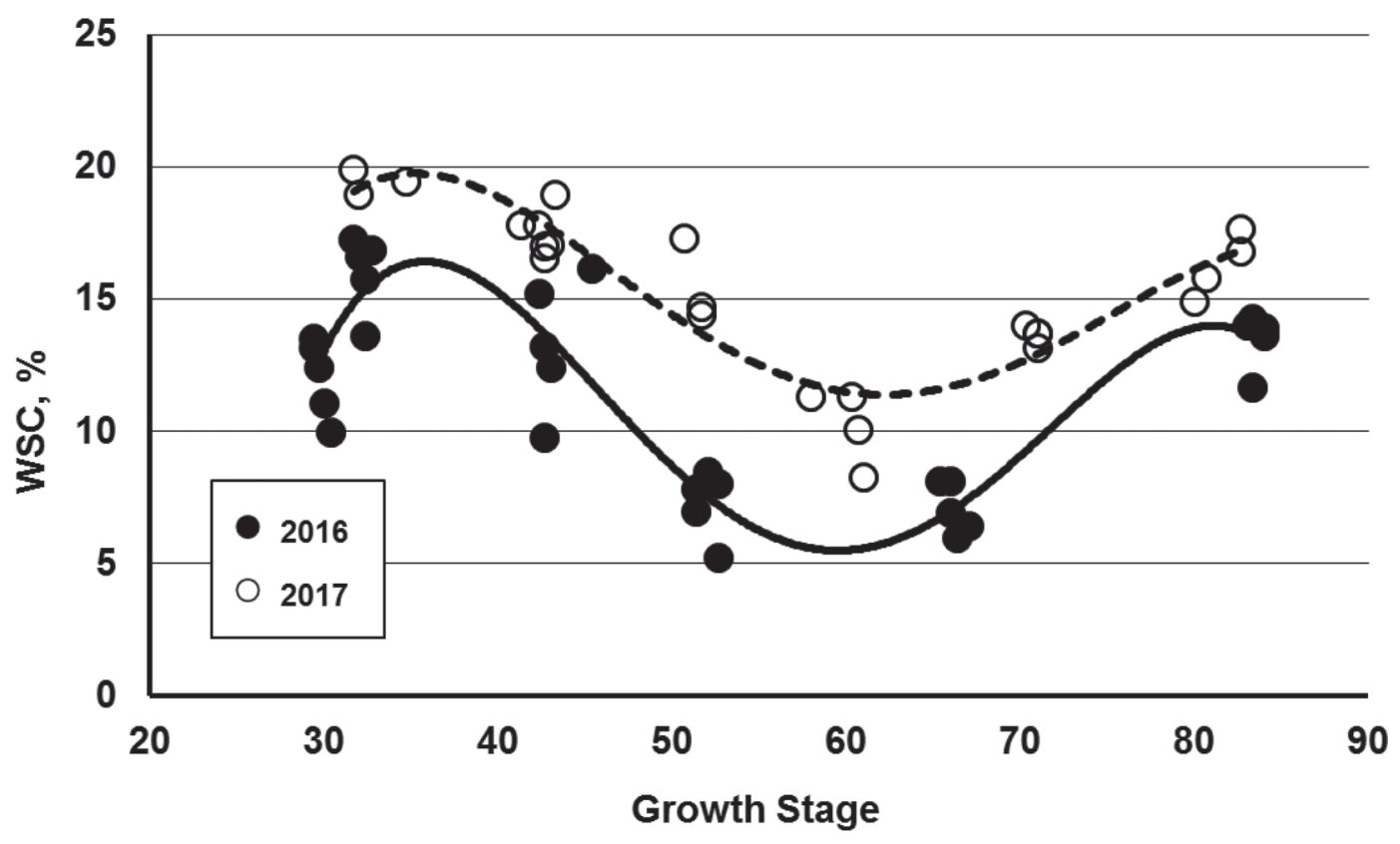

Figure 5. Regression relationships for water-soluble carbohydrates (WSC) on growth stage for triticale forages harvested during 2016 and 2017 at Marshfield, Wisconsin. Regression equations were as follows: $2016, \mathrm{Y}=-0.0000368 \mathrm{x}^{4}+0.00866 \mathrm{x}^{3}-0.726 \mathrm{x}^{2}+25.4 \mathrm{x}-300.7, \mathrm{R}^{2}=$ 0.776 , root mean squared error $(\mathrm{RMSE})=1.85 \% ; 2017, \mathrm{Y}=-0.0000173 \mathrm{x}^{4}+0.00422 \mathrm{x}^{3}-0.365 \mathrm{x}^{2}+13.0 \mathrm{x}-143.6, \mathrm{R}^{2}=0.839, \mathrm{RMSE}=1.36 \%$. The overall model for each regression was significant at $P<0.001$.

$\boldsymbol{C P}$. Many studies evaluating cereal grain forages have described reduced concentrations of $\mathrm{N}$ or $\mathrm{CP}$ as functions of growth stage or GDD (Cherney and Marten, 1982a; Coblentz et al., 2001; Gibson et al., 2007). Unlike other measured plant components that reflect dynamic changes in various carbohydrate pools during plant development, concentrations of $\mathrm{CP}$ in leaf blade, leaf sheath, stem, and inflorescence all decline with maturity (Cherney and Marten, 1982b). Generally, these responses have been curvilinear in nature, with the rate of $\mathrm{CP}$ decline slowing at advanced growth stages (Cherney and Marten, 1982a,b; Khorasani et al., 1997) or with greater with accumulations of GDD (Gibson et al., 2007). Means for specific harvest dates (Table 5) and our regression responses to advancing growth stage and accumulated GDD (Figure 6; Table 4) are consistent with previous studies; concentrations of $\mathrm{CP}$ declined cubically $(P<0.001)$ and quadratically $(P<$ 0.001 ) with growth stage in 2016 and 2017 , respectively, with excellent fits in each case $\left(\mathrm{R}^{2} \geq 0.946\right)$. Similarly, close cubic responses $(P<0.001)$ to accumulated GDD were found during both years $\left(\mathrm{R}^{2} \geq 0.956\right)$. Although concentrations of $\mathrm{CP}$ in triticale forages are increased by $\mathrm{N}$ fertilization rate (Gibson et al., 2007), the modest spring rate of $\mathrm{N}$ fertilization applied in the present study (52 kg of N/ha) yielded forages with $\mathrm{CP}$ concentrations of about $15 \%$ at boot stage, but CP declined to about $5 \%$ by the soft dough stage of growth. These comparisons of $\mathrm{CP}$ concentrations represent a clear trade-off for producers between DM yield and quality; however, it is unlikely that producers would prioritize the magnitude of $\mathrm{CP}$ concentrations in harvest timing decisions. Rather, a decision to maximize yield by delaying harvest until the soft dough stage of growth should be made with the clear knowledge that CP supplementation with other forages or feedstuffs will be necessary to meet the needs of virtually all livestock classes.

$\boldsymbol{A D I C P}$. The relationship between ADICP and growth stage or GDD has not often been discussed, but one study (Coblentz et al., 2001) showed that ADICP (\% of CP) increased with plant maturation in wheat, rye, and oat forages, but these increases were heavily associated with declining overall concentrations of CP rather than significant changes in the concentration of ADICP expressed on a DM basis. Concentrations of ADICP have implications for dairy nutrition with respect to availability of $\mathrm{CP}$ pool for ruminant digestion (Van Soest, 1982) as well as being a required input for calculation of energy by the summative approach, where truly digestible $\mathrm{CP}=\mathrm{CP} \times \mathrm{e}^{[-1.2 \times(\mathrm{ADICP} / \mathrm{CP})]}$ (Weiss et al., 1992; NRC, 2001). In the present study, triticale forages exhibited quadratic $(P<0.001)$ and cubic $(P<0.001)$ increases in ADICP $(\%$ of CP) with growth stage during 2016 and 2017 (Figure 6), respectively. These relationships were characterized by an 
excellent fit for $2017\left(\mathrm{R}^{2}=0.945\right)$ but much poorer fit $\left(\mathrm{R}^{2}=0.711\right)$ for 2016 , mostly due to greater variability for individual replicates at the vegetative and stem elongation stages of growth, which was not observed in more mature forages. Unlike regressions on growth stage, use of GDD as the independent variable (Table 4) yielded simple linear $(P<0.001)$ responses in both years, although the coefficient of determination was again poorer for $2016\left(\mathrm{R}^{2}=0.676\right)$ than $2017\left(\mathrm{R}^{2}=\right.$ 0.924). Overall, increases in ADICP were substantial; mean concentrations approximately doubled between the boot and soft dough stages of growth, reaching 6.18 and $7.11 \%$ of CP (Table 5) at the latter growth stage during 2016 and 2017, respectively.

$T \boldsymbol{D N}$ and $\boldsymbol{N} \boldsymbol{E}_{L}$. Overall, triticale was a relatively energy-dense forage, with mean energy estimates ranging between 60.4 and $74.9 \% \mathrm{TDN}\left(\mathrm{NE}_{\mathrm{L}}=1.36\right.$ and $1.72 \mathrm{Mcal} / \mathrm{kg}$ ) on specific harvest dates across 2 production years (Table 5). As such, concentrations of TDN were comparable with corn silage $(68.8 \%$; NRC, 2001) through the stem elongation stage of growth in $2016(70.2 \%)$ and through the late boot stage in 2017 (69.5\%). Much as discussed for WSC, energy estimates declined as plants matured, reaching a minimum at the anthesis stage of growth before increasing thereafter in response to increased concentrations of WSC or starch within the filling grain head; however, these responses to grain fill were muted somewhat by competing effects of increased lignification (Figure 3 ) that occurred concurrently. Although these general characteristics were similar across years, quadratic $(P<0.001)$ models best fit responses for TDN and $\mathrm{NE}_{\mathrm{L}}$ regressed on growth stage for 2016, but cubic $(P<0.001)$ models were selected for the second year of the trial (Figure
7). Regardless, growth stage effectively explained the variability in energy estimates $\left(R^{2} \geq 0.858\right)$. Regressions of energy estimates on GDD (Table 4) exhibited a quadratic $(P<0.001)$ relationship in all cases, also with very high coefficients of determination $\left(\mathrm{R}^{2} \geq\right.$ 0.876). Based on energy considerations, triticale forages should be harvested at boot stage for lactating cows, but harvests can be delayed until anthesis for gravid heifers with reduced energy requirements (NRC, 2001). However, management decisions attempting to match nutrient value with the requirements of specific livestock classes must be weighed against other factors, such as potential effects on DM yield or the urgency to remove triticale forages before establishing a subsequent double crop.

\section{Comments on $G D D>5^{\circ} \mathrm{C}$}

Generally, our results suggest that it will take about 300 GDD from January 1 for triticale forages to reach the boot stage of growth in central Wisconsin. To reach the soft dough stage, 750 to 800 GDD are required. One noticeable difference between regressions on growth stage compared with GDD was that those on growth stage were frequently higher ordered; of the 20 response variables regressed on both growth stage or GDD over 2 yr, 10 exhibited a higher-ordered model when a linear growth stage model was used as the independent or predictor variable. In 7 cases, regression models maintained the same number of polynomial terms, wheraes regressions of whole-plant ash and ADICP for 2016 as well as CP for 2017 were more complex with GDD as the independent variable. It is important to note that GDD and growth stage are closely related to chrono-

Table 5. Concentrations of CP, neutral detergent insoluble CP (NDICP), acid detergent insoluble CP (ADICP), TDN, and NE $\mathrm{L}_{\mathrm{L}}$ for triticale forages harvested at Marshfield, Wisconsin, during 2016 and 2017

\begin{tabular}{|c|c|c|c|c|c|c|c|c|c|c|c|}
\hline \multirow{2}{*}{$\begin{array}{l}\text { Harvest } \\
\text { date }\end{array}$} & \multirow{2}{*}{$\begin{array}{l}\text { Descriptive } \\
\text { growth stage }\end{array}$} & \multicolumn{2}{|c|}{$\begin{array}{c}\text { CP, } \\
\% \text { of DM }\end{array}$} & \multicolumn{2}{|c|}{$\begin{array}{l}\text { NDICP, } \\
\% \text { of CP }\end{array}$} & \multicolumn{2}{|c|}{$\begin{array}{l}\text { ADICP, } \\
\% \text { of } \mathrm{CP}\end{array}$} & \multicolumn{2}{|c|}{$\begin{array}{c}\text { TDN, } \\
\% \text { of DM }\end{array}$} & \multicolumn{2}{|c|}{$\begin{array}{c}\mathrm{NE}_{\mathrm{L}}, \\
\mathrm{Mcal} / \mathrm{kg}\end{array}$} \\
\hline & & Mean $^{1}$ & $\mathrm{SD}^{1}$ & Mean & SD & Mean & $\mathrm{SD}$ & Mean & SD & Mean & SD \\
\hline \multicolumn{12}{|l|}{2016} \\
\hline May 12 & Vegetative & 23.9 & 1.12 & 13.8 & 0.89 & 3.41 & 0.905 & 69.4 & 0.65 & 1.58 & 0.016 \\
\hline May 19 & Elongation & 19.1 & 1.62 & 14.4 & 0.57 & 3.91 & 0.857 & 70.2 & 0.68 & 1.60 & 0.017 \\
\hline May 25 & Boot & 15.4 & 1.24 & 13.3 & 1.57 & 3.50 & 0.346 & 65.4 & 2.48 & 1.48 & 0.061 \\
\hline July 1 & Soft dough & 5.9 & 0.58 & 13.8 & 0.51 & 6.18 & 0.545 & 64.4 & 1.36 & 1.46 & 0.033 \\
\hline \multicolumn{12}{|l|}{2017} \\
\hline May 24 & Elongation & 18.0 & 0.58 & 10.0 & 0.22 & 2.70 & 0.325 & 74.9 & 0.92 & 1.72 & 0.023 \\
\hline May 29 & Early boot & 13.7 & 0.89 & 9.5 & 0.67 & 2.94 & 0.282 & 71.1 & 0.59 & 1.62 & 0.014 \\
\hline June 2 & Boot & 12.1 & 1.10 & 11.0 & 1.29 & 3.52 & 0.707 & 69.5 & 2.47 & 1.58 & 0.060 \\
\hline June 8 & Early anthesis & 10.4 & 1.21 & 11.3 & 0.46 & 4.55 & 0.615 & 64.5 & 1.15 & 1.46 & 0.028 \\
\hline June 23 & Watery seed & 6.0 & 0.12 & 11.9 & 2.57 & 6.41 & 0.545 & 63.4 & 0.29 & 1.43 & 0.007 \\
\hline
\end{tabular}

${ }^{1}$ Mean and SD based on 5 field replications of each harvest date for 2016 and 4 field replications for 2017. 

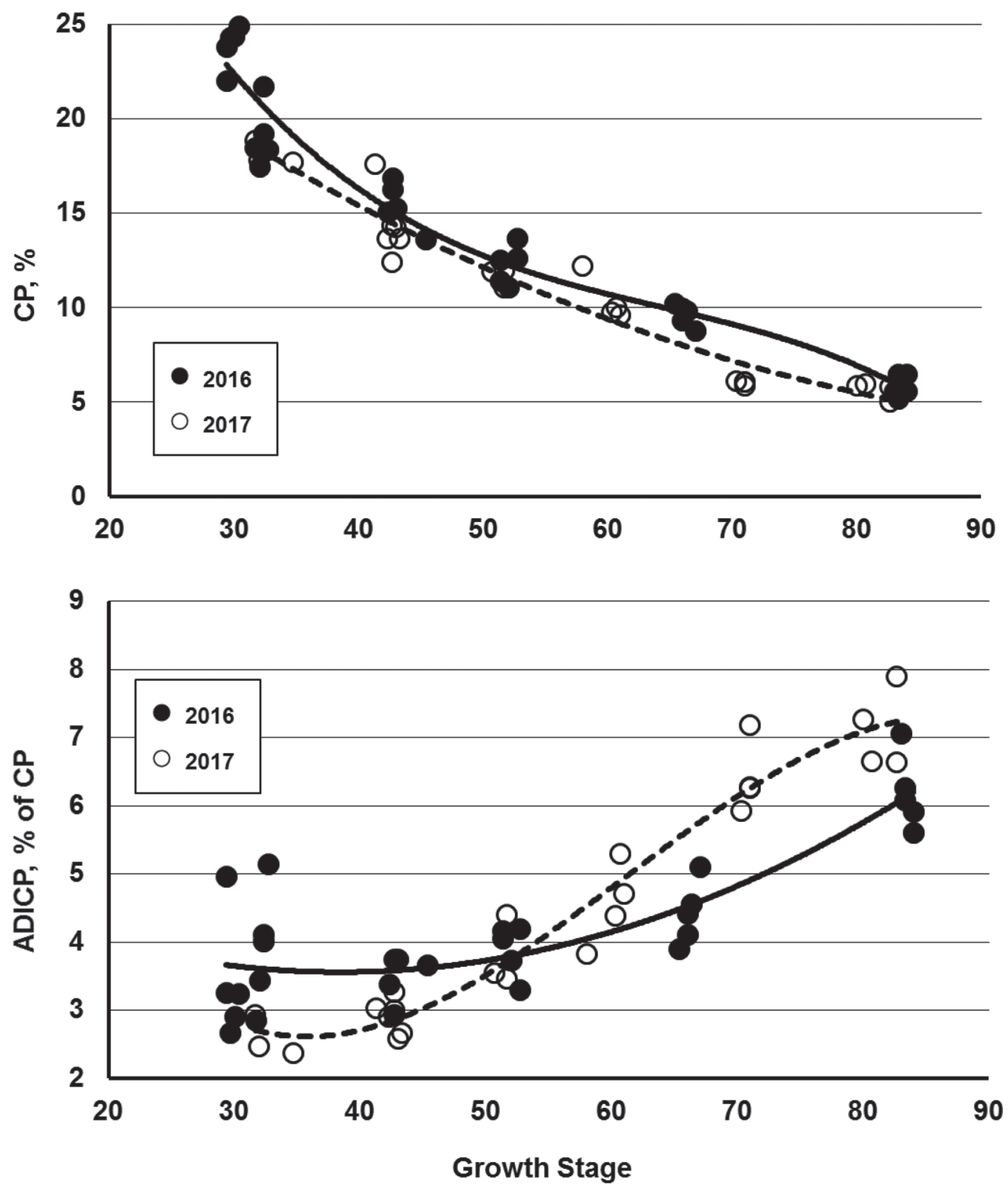

Figure 6. Regression relationships for CP (top) and acid detergent insoluble CP (ADICP; bottom) on growth stage for triticale forages harvested during 2016 and 2017 at Marshfield, Wisconsin. Regression equations for CP were as follows: 2016, $\mathrm{Y}=-0.000174 \mathrm{x}^{3}+0.0335 \mathrm{x}^{2}-2.31 \mathrm{x}$ $+66.2, \mathrm{R}^{2}=0.950$, root mean squared error $(\mathrm{RMSE})=1.46 \% ; 2017, \mathrm{Y}=0.00262 \mathrm{x}^{2}-0.562 \mathrm{x}+33.7, \mathrm{R}^{2}=0.946, \mathrm{RMSE}=1.09 \%$. Regression equations for ADICP were as follows: 2016, $\mathrm{Y}=0.00127 \mathrm{x}^{2}-0.0980 \mathrm{x}+5.45, \mathrm{R}^{2}=0.711, \mathrm{RMSE}=0.617 \%$ of $\mathrm{CP} ; 2017, \mathrm{Y}=-0.0000715 \mathrm{x}^{3}+$ $0.0131 \mathrm{x}^{2}-0.663 \mathrm{x}+12.84, \mathrm{R}^{2}=0.945, \mathrm{RMSE}=0.448 \%$ of $\mathrm{CP}$. The overall model for each regression was significant at $P<0.001$.

logical time but not in identical ways; for GDD, these relationships were linear for both $2016(\mathrm{GDD}=14.1 \mathrm{x}$ $\left.-55.0 ; \mathrm{R}^{2}=0.997\right)$ and $2017(\mathrm{GDD}=13.6 \mathrm{x}-73.5$; $\left.\mathrm{R}^{2}=0.995\right)$, where $\mathrm{x}=$ days from May 15 . In contrast, the relationship between growth stage and days for this time period was quadratic for $2016\left(\mathrm{Y}=-0.017 \mathrm{x}^{2}+\right.$ $\left.2.6 \mathrm{x}-11 ; \mathrm{R}^{2}=0.999\right)$ and $2017\left(\mathrm{Y}=-0.012 \mathrm{x}^{2}+\right.$ $\left.2.2 \mathrm{x}-12 ; \mathrm{R}^{2}=0.987\right)$, where the rate of morphological development slowed as a function of time, particularly between the anthesis and soft dough stages of growth.

\section{Kinetics of IVDMD}

Fractions $\boldsymbol{A}, \boldsymbol{B}$, and $\boldsymbol{C}$. Means for various regression parameters describing kinetics of IVDMD for triticale forages harvested from the stem elongation 
through soft dough stages of growth during 2016 are summarized in Table 6 . The regressions of A, B, and U pools on growth stage (Figure 8) depict dynamic rather than static relationships between various DM pools as plants develop morphologically. Overall, fraction A declined with plant maturity in a close $\left(\mathrm{R}^{2}=0.980\right)$, quartic $(P<0.001)$ relationship with growth stage; however, slight increases were observed after anthesis in response to greater concentrations of WSC (Figure $5)$ and the initiation of grain fill. Fraction B exhibited a quadratic $(P<0.001)$ response across growth stages, increasing to $>50 \%$ of total plant DM during the heading and anthesis stages of growth in response to plants partitioning increased percentages of DM into struc-
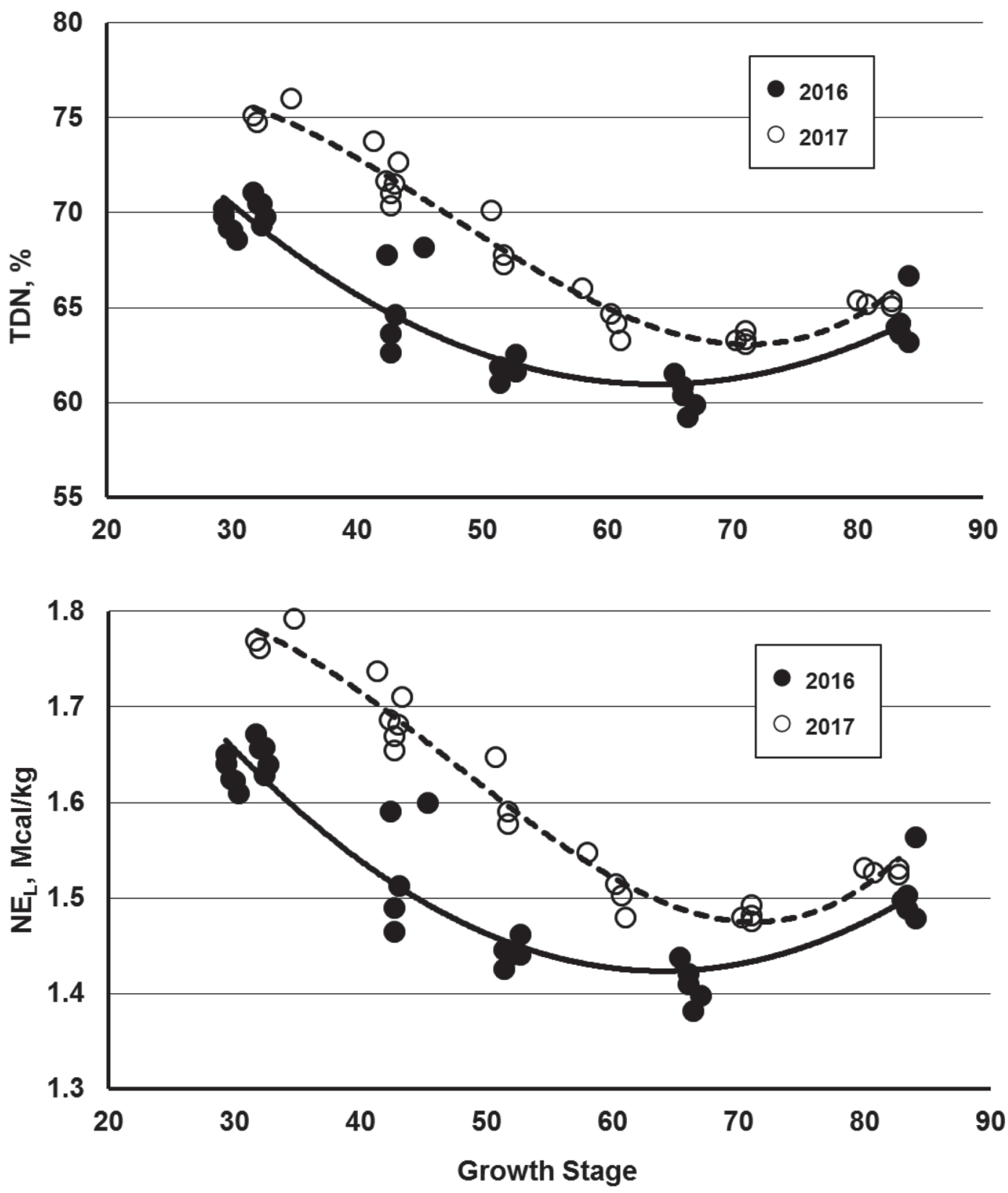

Figure 7. Regression relationships for TDN and $\mathrm{NE}_{\mathrm{L}}$ on growth stage for triticale forages harvested during 2016 and 2017 at Marshfield, Wisconsin. Regression relationships for TDN were as follows: $2016, \mathrm{Y}=0.00820 \mathrm{x}^{2}-1.05 \mathrm{x}+94.5, \mathrm{R}^{2}=0.858$, root mean squared error (RMSE) $=1.51 \% ; 2017, \mathrm{Y}=0.000251 \mathrm{x}^{3}-0.0358 \mathrm{x}^{2}+1.27 \mathrm{x}+63.1, \mathrm{R}^{2}=0.962, \mathrm{RMSE}=0.90 \%$. Regression equations for NE $\mathrm{L}_{\mathrm{L}}$ on growth stage were as follows: $2016, \mathrm{Y}=0.000201 \mathrm{x}^{2}-0.0257 \mathrm{x}+2.20, \mathrm{R}^{2}=0.858, \mathrm{RMSE}=0.037 \mathrm{Mcal} / \mathrm{kg} ; 2017, \mathrm{Y}=0.00000616 \mathrm{x}^{3}-0.000878 \mathrm{x}^{2}+0.0313 \mathrm{x}+1.42$, $\mathrm{R}^{2}=0.963, \mathrm{RMSE}=0.022 \mathrm{Mcal} / \mathrm{kg}$. The overall model for each regression was significant at $P<0.001$. 
tural fiber but declining with the initiation of grain fill. Fraction U increased across growth stages, exhibiting a close $\left(\mathrm{R}^{2}=0.980\right)$, cubic $(P<0.001)$ relationship that plateaued at approximately $30 \%$ of total DM at the soft dough stage of growth. Based on in situ procedures, other cereal grain forages (oat, wheat, and rye) have exhibited similar plateaus with respect to rumen unavailability at advanced growth stages (Coblentz et al., 2000); this response represents the collective and competing effects of (1) reduced proportions of leaf blade and sheath (Cherney and Marten, 1982b; Walker et al., 1990); (2) increasing proportions of stem tissue, at least until the initiation of grain fill, that become increasingly lignified as the plant matures (Cherney and Marten, 1982b; Coblentz et al., 2000), and (3) assimilation of highly digestible carbohydrate within the filling seed head (Cherney and Marten, 1982b), where the grain head can exceed $50 \%$ of the total DM within the plant (Coblentz et al., 2000).

$\boldsymbol{K}_{\boldsymbol{d}}$. Between stem elongation and the soft dough stage of growth, rates of IVDMD slowed by approximately $50 \%$ from 0.071 to $0.035 / \mathrm{h}$, respectively. Variability among replicates at specific growth stages (Table 6) was about 6 times greater at stem elongation $(\mathrm{SD}=0.0084 / \mathrm{h})$ compared with the anthesis or soft dough stages of growth $(\mathrm{SD}=0.0013$ and $0.0015 / \mathrm{h}$, respectively). Regardless, the regression of $K_{d}$ on growth stage (Figure 9) indicated that $\mathrm{K}_{\mathrm{d}}$ declined quadratically $(P<0.001)$ with plant maturation, with little change between the anthesis and soft dough growth stages, both of which exhibited rates $<0.040 / \mathrm{h}$. Although $\mathrm{K}_{\mathrm{d}}$ has not often been related to growth stage by regression procedures, declining quadratic relationships have been reported for wheat, oat, and rye forages harvested over similar growth stages and evaluated by in situ procedures (Coblentz et al., 2000). In that study, the reported relationship between $\mathrm{K}_{\mathrm{d}}$ and growth stage for oats $\left(\mathrm{K}_{\mathrm{d}}=0.00001 \mathrm{x}^{2}-0.0024 \mathrm{x}+0.139, \mathrm{R}^{2}=\right.$ $0.897)$ was very similar to that reported in the present study for triticale, whereas relationships for wheat and rye suggested that $K_{d}$ declined at a more rapid rate as those forages matured.

Lag Time. Estimates of lag time from DM disappearance kinetics ranged from 2.50 to $6.73 \mathrm{~h}$ on specific harvest dates (Table 6) and exhibited a quadratic $(P$ $<0.001)$ relationship with growth stage (Figure 10). In practical terms, lag times were generally static through the anthesis stage of growth before declining sharply in association with grain fill at soft dough stage.

Apparent IVDMD. Apparent IVDMD following 30 $\mathrm{h}$ (IVDMD30) or $48 \mathrm{~h}$ (IVDMD48) of incubation generally exhibited parallel responses across growth stage (Figure 11), with the mean differential between incubation times (IVDMD48 - IVDMD30) ranging

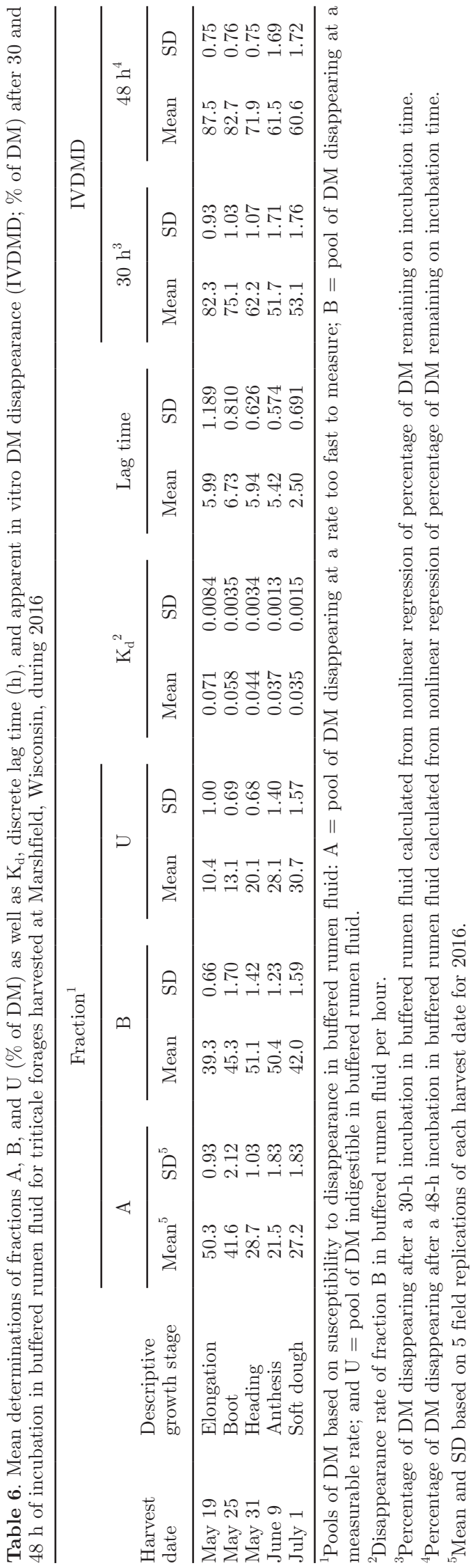




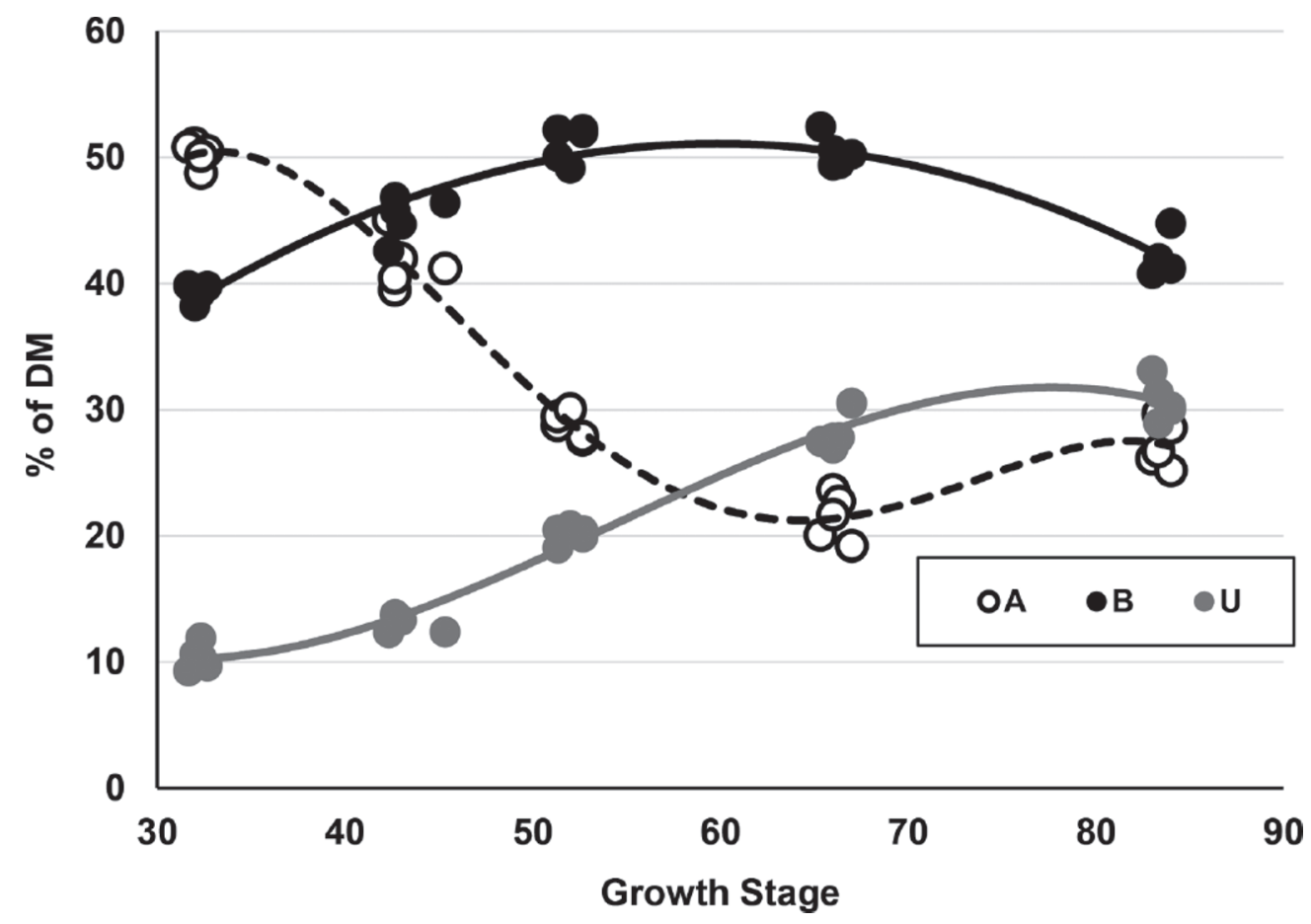

Figure 8. Changes in DM pools as affected by growth stage for triticale forages harvested in Marshfield, Wisconsin, during 2016, where $\mathrm{A}=$ pool that disappears at a rate too fast to measure, $\mathrm{B}=$ pool that disappears at a measurable rate, and $\mathrm{U}=$ pool that is indigestible in buffered rumen fluid. All pool sizes were determined via in vitro procedures for DM disappearance. Regression curves were defined as follows: A $=-0.0000448 \mathrm{x}^{4}+0.0107 \mathrm{x}^{3}-0.905 \mathrm{x}^{2}+31.3 \mathrm{x}-327.9, \mathrm{R}^{2}=0.980$, root mean squared error $(\mathrm{RMSE})=1.70 \% ; \mathrm{B}=-0.0160 \mathrm{x}^{2}+1.92 \mathrm{x}-6.2$, $\mathrm{R}^{2}=0.907, \mathrm{RMSE}=1.55 \% ; \mathrm{U}=-0.000433 \mathrm{x}^{3}+0.0707 \mathrm{x}^{2}-3.16 \mathrm{x}+53.0, \mathrm{R}^{2}=0.980, \mathrm{RMSE}=1.24 \%$. The overall regression model for each fraction was significant at $P<0.001$.

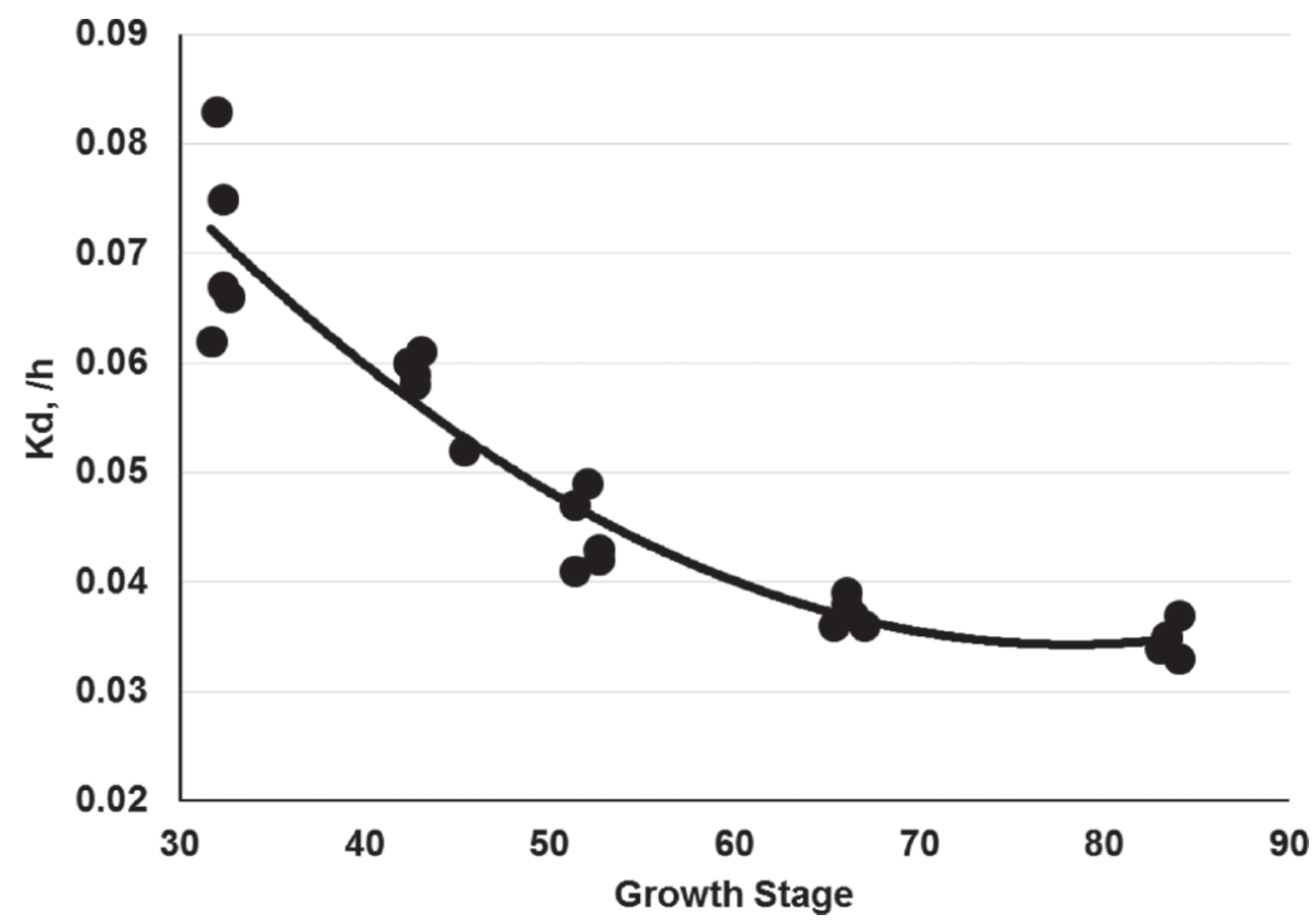

Figure 9. Changes in in vitro DM disappearance rate $\left(K_{d}\right)$ of fraction B (defined as pool that disappears at a measurable rate) as a function of growth stage for triticale forages harvested at Marshfield, Wisconsin, during 2016. Regression equation was defined as follows: $\mathrm{K}_{\mathrm{d}}=$ $0.0000176 \mathrm{x}^{2}-0.00275 \mathrm{x}+0.142, \mathrm{R}^{2}=0.917$, root mean squared error $=0.0043 / \mathrm{h}$. The overall regression was significant at $P<0.001$. 


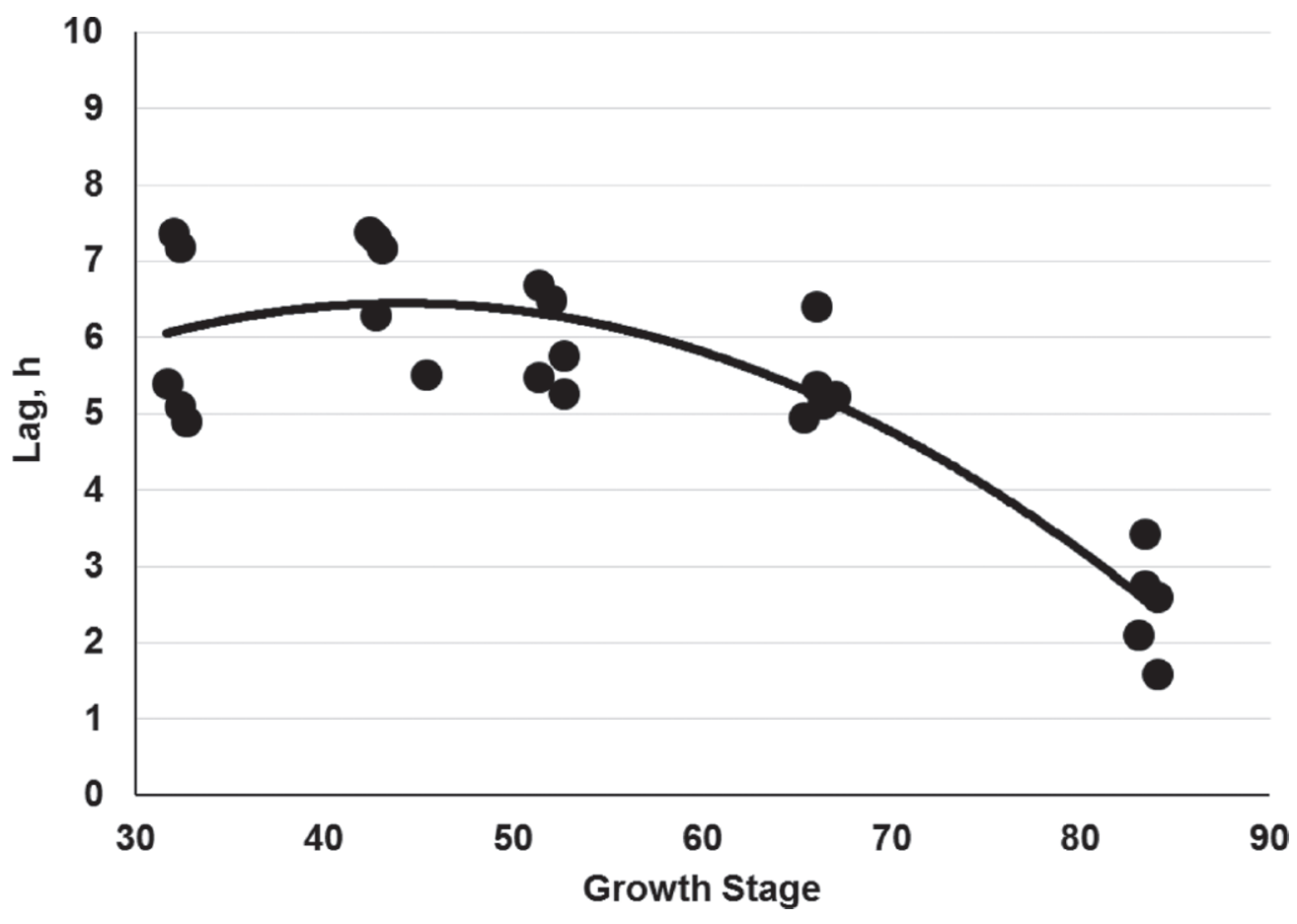

Figure 10. Regression relationship between lag time and growth stage of triticale forages harvested in Marshfield, Wisconsin, during 2016. Lag time was estimated from in vitro DM disappearance kinetics. Regression equation was defined as follows: lag time $=-0.00252 \mathrm{x}^{2}+0.222 \mathrm{x}$ $+1.54, \mathrm{R}^{2}=0.788$, root mean squared error $=0.805 \mathrm{~h}$. The overall regression was significant at $P<0.001$.

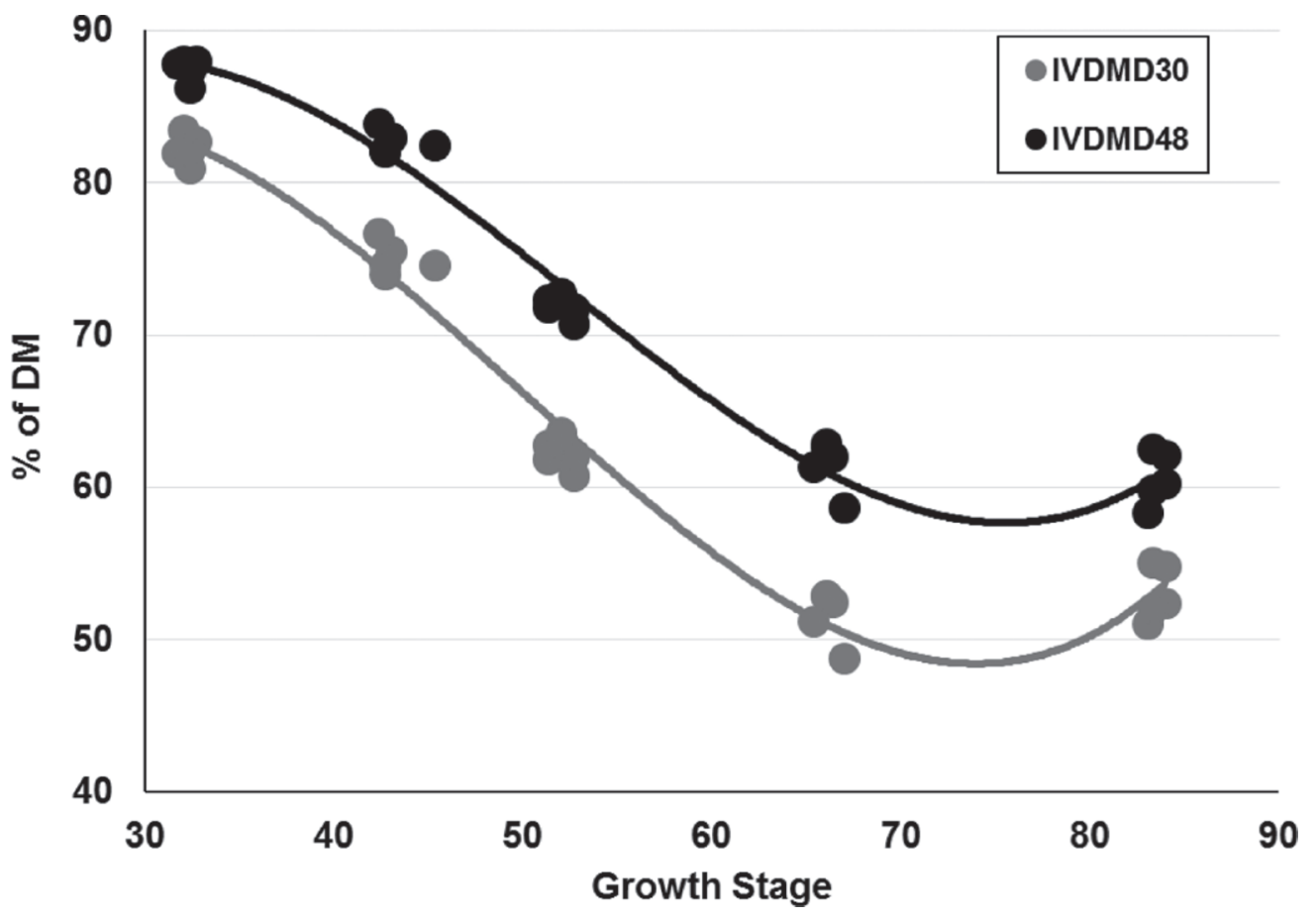

Figure 11. Regression of apparent in vitro DM disappearance after 30-h (IVDMD30) or 48-h (IVDMD48) incubations as determined from nonlinear regressions of DM remaining on incubation time for triticale forages harvested in Marshfield, Wisconsin, during 2016. Regressions were defined as follows: IVDMD30 $=0.000641 \mathrm{x}^{3}-0.0958 \mathrm{x}^{2}+3.66 \mathrm{x}+42.7, \mathrm{R}^{2}=0.982$, root mean squared error $(\mathrm{RMSE})=1.75 \%$; IVDMD48 $=$ $0.000619 \mathrm{x}^{3}-0.0974 \mathrm{x}^{2}+4.12 \mathrm{x}+35.4, \mathrm{R}^{2}=0.984, \mathrm{RMSE}=1.51 \%$. Both overall regression equations were significant at $P<0.001$. 
from 5.2 to 9.8 percentage units on individual harvest dates (Table 6). For both incubation times, relationships with growth stage were explained by cubic $(P<$ 0.001) models with very high coefficients of determination $\left(\mathrm{R}^{2} \geq 0.982\right)$. Generally, mean apparent IVDMD30 and IVDMD48 were very high during stem elongation $(\geq 82.3 \%$; Table 6$)$ and then declined steadily through the anthesis stage of growth $(\leq 61.5 \%)$ before increasing slightly in response to grain fill. Two key summary points are important: (1) triticale forages are highly digestible at the stem elongation or boot stages of growth, which is consistent with many studies including a variety of cereal grain forages (Cherney and Marten, 1982a; Walker et al., 1990; Coblentz et al., 2000), and (2) the DM digestibility of triticale stabilizes, and may even increase, during grain fill. This latter response has been described for other cereal grain forages (Walker et al., 1990; West et al., 1991); however, the final collective effect of grain fill is dependent on species (Helsel and Thomas, 1987; Coblentz et al., 2000) as well as the competing effects of increased lignification and reduced digestibility of leaf, leaf sheath, and stem juxtaposed against the accumulation of highly digestible carbohydrate within the seed head (Cherney and Marten, 1982b; Walker et al., 1990).

Regressions on GDD. While regressions of DM yield, concentrations of $\mathrm{N}$, and total $\mathrm{N}$ uptake on GDD for triticale grown in Iowa have been reported (Schwarte et al., 2005; Gibson et al., 2007), similar regressions on parameter estimates for DM disappearance kinetics have not. These relationships are included (Table 7 ), and generally they exhibit very high coefficients of determination $\left(\mathrm{R}^{2} \geq 0.916\right)$ for all parameters except lag time $\left(\mathrm{R}^{2}=0.715\right)$. Although the most appropriate polynomial model varies somewhat from regressions on growth stage, in part because the 2 independent variables have different relationships with chronological time, growth stage and GDD are obviously interrelated and both depict similar changing patterns in digestibility characteristics as GDD accumulate or as plants mature.

\section{CONCLUSIONS}

From a management perspective, the nutritional characteristics of triticale forages are heavily influenced by 2 competing processes. These include the normal maturation effects that reduce the quality of most forages juxtaposed against the physiological process of grain fill, which can dilute concentrations of forage fiber components, increase energy density, and improve DM digestibility at advanced plant growth stages. Despite this juxtaposition of competing physiological processes, nutritive characteristics of triticale harvested at the 
boot stage of growth are more favorable for lactating cows compared with those harvested at later stages of maturity, primarily due to avoidance of the most negative aspects of the normal maturation process, such as increased concentrations of fiber components and reduced concentrations of $\mathrm{CP}$. However, an approximately $70 \%$ yield drag also can be associated with this management choice. Furthermore, a comparison of respective energy yields for 2016 (2,488 vs. 8,141 kg of TDN/ha) and 2017 (1,033 vs. $3,520 \mathrm{~kg}$ of TDN/ha) suggests that yields of energy are mostly driven by the differential in DM yield. Despite these differences, an informed management decision for lactating cows may still favor a boot-stage harvest because of superior nutritional characteristics, a need to plant a corn double crop expeditiously, or both. Harvest timing of triticale forages for other livestock classes would appear to be more flexible, but prioritizing a double crop of corn, soybeans, or sorghum may reduce the negative effects on DM yield to a secondary consideration.

\section{ACKNOWLEDGMENTS}

This research was supported through appropriated USDA Agricultural Research Service (Washington, DC) CRIS funds (project no. 5090-12630-005-00D). Mention of trade names or commercial products in this article is solely for the purpose of providing specific information and does not imply either recommendation or endorsement by the USDA.

\section{REFERENCES}

Acosta, Y. M., C. C. Stallings, C. E. Polan, and C. N. Miller. 1991. Evaluation of barley silage harvested at boot and soft dough stages. J. Dairy Sci. 74:167-176.

Baron, V. S., A. Aasen, M. Oba, A. C. Dick, D. F. Salmon, J. A. Basarab, and C. F. Stevenson. 2012. Swath-grazing potential for small-grain species with a delayed planting date. Agron. J. 104:393-404.

Bergen, W. G., T. M. Byrem, and A. L. Grant. 1991. Ensiling characteristics of whole-crop small grains harvested at milk and dough stages. J. Anim. Sci. 69:1766-1774.

Cherney, J. H., and G. C. Marten. 1982a. Small grain crop forage potential: I. Biological and chemical determinants of quality and yield. Crop Sci. 22:227-231.

Cherney, J. H., and G. C. Marten. 1982b. Small grain crop forage potential: II. Interrelationships among biological, chemical, morphological, and anatomical determinants of quality. Crop Sci. $22: 240-245$.

Coblentz, W. K., K. P. Coffey, J. E. Turner, D. A. Scarbrough, J. S. Weyers, K. F. Harrison, Z. B. Johnson, L. B. Daniels, C. F Rosenkrans Jr., D. W. Kellogg, and D. S. Hubbell III.. 2000. Effect of maturity on degradation kinetics of sod-seeded cereal grains in northern Arkansas. J. Dairy Sci. 83:2499-2511.

Coblentz, W. K., K. P. Coffey, J. E. Turner, D. A. Scarbrough, J. S. Weyers, K. F. Harrison, Z. B. Johnson, L. B. Daniels, C. F. Rosenkrans Jr., D. W. Kellogg, and D. S. Hubbell III.. 2001. Ruminal nitrogen disappearance from sod-seeded cereal grains in northern Arkansas. Anim. Feed Sci. Technol. 89:17-32.
Coblentz, W. K., N. M. Esser, G. E. Brink, P. C. Hoffman, and M. G. Bertram. 2013a. Grazing management for fall-grown oat forages. Focus on Forage 15(3):1-4. University of Wisconsin Cooperative Extension Service, Madison, WI.

Coblentz, W. K., S. E. Nellis, P. C. Hoffman, M. B. Hall, P. J. Weimer, N. M. Esser, and M. G. Bertram. 2013b. Unique interrelationships between fiber composition, water-soluble carbohydrates, and in vitro gas production for fall-grown oat forages. J. Dairy Sci. 96:7195-7209.

Coblentz, W. K., and R. P. Walgenbach. 2010. Fall growth, nutritive value, and estimation of total digestible nutrients for cerealgrain forages in the north-central United States. J. Anim. Sci. $88: 383-399$.

Drake, D. J., and S. B. Orloff. 2005. Simulating grazing effects on triticale forage yield. Forage Grazinglands 3. https://doi.org/10 .1094/FG-2005-0314-01-RS

Dubois, M., K. A. Gilles, J. K. Hamilton, P. A. Rebers, and F. Smith. 1956. Colorimetric method for determination of sugars and related substances. Anal. Chem. 28:350-356.

Edmisten, K. L., J. T. Green Jr., J. P. Mueller, and J. C. Burns. 1998. Winter annual small grain forage potential. I. Dry matter yield in relation to morphological characteristics of four small grain species at six growth stages. Commun. Soil Sci. Plant Anal. 29:867-879.

Ford, C. W., I. M. Morrison, and J. R. Wilson. 1979. Temperature effects on lignin, hemicellulose, and cellulose in tropical and temperate grasses. Aust. J. Agric. Res. 30:621-633.

Gibson, L. R., C. D. Nance, and D. L. Karlen. 2007. Winter triticale response to nitrogen fertilization when grown after corn or soybean. Agron. J. 99:49-58.

Griggs, T. C. 2006. Fall and spring forage production and quality of winter cereals seeded at three fall dates. Forage Grazinglands 4. https://doi.org/10.1094/FG-2006-0711-01-RS.

Harmoney, K. R., and C. A. Thompson. 2005. Fertilizer rate and placement alters triticale forage yield and quality. Forage Grazinglands 3. https://doi.org/10.1094/FG-2005-0512-01-RS.

Harper, M. T., J. Oh, F. Giallongo, G. W. Roth, and A. N. Hristov 2017. Inclusion of wheat and triticale silage in the diet of lactating dairy cows. J. Dairy Sci. 100:6151-6163.

Helsel, Z. R., and J. W. Thomas. 1987. Small grains for silage. J. Dairy Sci. 70:2330-2338.

Kennelly, J. J., and Z. G. Weinberg. 2003. Small grains silage. Pages 749-780 in Silage Science and Technology. D. R. Buxton, R. E. Muck, and J. H. Harrison, ed. American Society of Agronomy, Crop Science Society of America, and Soil Science Society of America, Madison, WI.

Khorasani, G. R., P. E. Jedel, J. H. Helm, and J. J. Kennelly. 1997 Influence of stage of maturity on yield components and chemical composition of cereal grain silages. Can. J. Anim. Sci. 77:259-267.

Kilcer, T., J. Cherney, K. Czymmek, and Q. Ketterings. 2010. Winter triticale forage. Fact sheet no. 56. Cornell University Cooperative Extension, Ithaca, NY.

Maloney, T. S., E. S. Oplinger, and K. A. Albrecht. 1999. Small grains for fall and spring forage. J. Prod. Agric. 12:488-494.

McCartney, D. H., and A. S. Vaage. 1994. Comparative yield and feeding value of barley, oat, and triticale silages. Can. J. Anim. Sci. 74:91-96.

McCormick, J. S., R. M. Sulc, D. J. Barker, and J. E. Beuerlein. 2006. Yield and nutritive value of autumn-seeded winter-hardy and winter-sensitive annual forages. Crop Sci. 46:1981-1989.

McDonald, P., A. R. Henderson, and S. J. E. Heron. 1991. The Biochemistry of Silage. 2nd ed. Chalcombe, Buckinghamshire, UK.

Meyer, J. H., W. C. Weir, L. G. Jones, and J. L. Hull. 1957. The influence of stage of maturity on the feeding value of oat hay. J. Anim. Sci. 16:623-632.

Muck, R. E., and L. Kung Jr. 2007. Silage production. Pages 617-633 in Forages Vol. II. The Science of Grassland Agriculture. R. F. Barnes, C. J. Nelson, K. J. Moore, and M. Collins, ed. Blackwell Professional, Ames, IA.

NOAA (National Oceanic and Atmospheric Administration). 2002. Monthly station normals of temperature, precipitation, and heating and cooling degree days 1971-2000. Climatography of the 
United States no. 81. National Climatic Data Center, NESDIS, NOAA, Asheville, NC.

NRC. 2001. Nutrient Requirements of Dairy Cattle. 7th rev. ed. National Academy Press, Washington, DC.

SAS Institute. 2010. SAS. Version 9.3. SAS Institute Inc., Cary, NC.

Schwarte, A. J., L. R. Gibson, D. L. Karlen, M. Liebman, and J. L. Jannink. 2005. Planting date effects on winter triticale dry matter and nitrogen accumulation. Agron. J. 97:1333-1341.

Stauss, R. 1994. Compendium of Growth Stage Identification Keys for Mono- and Dicotyledonous Plants. Extended BBCH Scale. CibaGeigy AG, Basel, Switzerland.

Van Soest, P. J. 1982. Nutritional Ecology of the Ruminant. Cornell Univ. Press, Ithaca, NY.
Van Soest, P. J., J. B. Robertson, and B. A. Lewis. 1991. Methods for dietary fiber, neutral detergent fiber, and nonstarch polysaccharides in relation to animal nutrition. J. Dairy Sci. 74:3583-3597.

Walker, D. W., C. P. West, R. K. Bacon, D. E. Longer, and K. E. Turner. 1990. Changes in forage yield and composition of wheat and wheat-ryegrass mixtures with maturity. J. Dairy Sci. 73:12981303.

Weiss, W. P., H. R. Conrad, and N. R. St-Pierre. 1992. A theoreticallybased model for predicting total digestible nutrient values of forages and concentrates. Anim. Feed Sci. Technol. 39:95-110.

West, C. P., D. W. Walker, R. K. Bacon, D. E. Longer, and K. E. Turner. 1991. Phenological analysis of forage yield and quality in winter wheat. Agron. J. 83:217-224. 